\title{
Tricalcium citrate (TCC) and health
}

\begin{abstract}
Background: Calcium plays a key role in physiology and bone health. Inadequate intake is common in certain groups of the population.
\end{abstract}

Methods: Systematic evaluation of relevant literature using medical (Medline) and nutrition databases as well as inclusion of physiological studies, randomized controlled trials, cohort studies, meta-analyses and dietary guidelines

Results and Conclusions: Despite the essentiality of calcium for bone growth and maintenance, clinical studies and meta-analyses on positive effects of calcium supplementation on skeletal health and osteoporosis have shown contradictory results. Dietary recommendations for calcium have therefore been developed primarily in order to meet physiological needs. For individuals who are not able or willing to cover their recommended calcium requirements $(1000-1300 \mathrm{mg} / \mathrm{d}$ for adolescents and adults in industrialized countries) from dietary sources, numerous calcium supplements such as calcium carbonate $\left(\mathrm{CaCO}_{3}\right)$ or Tricalcium Dicitrate $* 4 \mathrm{H}_{2} \mathrm{O}$ (TCC) are available. Of these, TCC is characterized by its good compliance, sufficient calcium content, a better absorbability than $\mathrm{CaCO}_{3}$ and a gastric acid-independent intestinal absorption. Despite the generally poor association between acute effects of high calcium absorption on serum calcium concentration and long term effects on BMD, bone structure and fracture incidence, a higher intake of TCC has led to increased bone mineral density and reduced bone loss in a number of randomized controlled studies in elderly women. Moreover, whereas in some clinical trials and meta-analyzes, (supplemental) calcium caused an increased risk for cardiovascular diseases and stroke as well as for kidney stones, a larger number of studies did not show this or even the opposite, in particular with TCC.

Conclusions: Supplemental TCC is a good opportunity to allow subjects at risk of inadequate calcium supply a calcium intake according to common recommendations. Small positive effects of TCC on bone health have been shown in numerous studies, but the study results are not fully consistent. There is no evidence for an increased cardiovascular disease or renal stone risk.
Volume 6 Issue 5 - 2017

\author{
Michael de Vrese,' Gerhard Gerstner² \\ 'M de Vrese, Hamburg, Germany \\ ${ }^{2} \mathrm{G}$ Gerstner, Jungbunzlauer Ladenburg GmbH, Germany
}

Correspondence: Michael de Vrese, Am Krähenberg I5, D-22587 Hamburg, Germany, Tel +004940860594, Fax ++494086642549, Email michael0devrese@googlemail.com

Received: September 25, 2016 | Published: June 02, 2017

\section{Role of calcium and intake recommendations}

\section{Physiological role of calcium}

The human organism contains about $1200 \mathrm{~g}$ of calcium, which is the 5 th most abundant element in the human body accounting for $1-2 \%$ of adult body weight. Almost $99 \%$ of calcium is incorporated in the skeleton $(0.5 \%$ in the teeth), where it brings hardness and also serves as a reservoir for metabolically used calcium. Hardness is provided to vertebrate bones by a form of calcium phosphate, which is close to the composition of hydroxylapatite $\left(\mathrm{Ca}_{10}(\mathrm{OH}) 2\left(\mathrm{PO}_{4}\right)_{6}\right)$ embedded in a protein matrix, mainly collagen fibrils.

Less than $1 \%$ ( $10 \mathrm{~g}$ in adults) of total calcium is found in the cells of soft tissues and in blood plasma and other extra cellular fluids. ${ }^{1,2}$ This mobile, metabolically available part of calcium is required for a wide range of essential body functions including intra- and extracellular signaling and nerve impulse transmission, muscle function, vascular contraction and vasodilatation, blood clotting or enzyme activation and mediation of hormonal effects. ${ }^{3,4}$ Abnormally high serum calcium concentrations (hypercalcemia) may result in lethargy, loss of appetite and/or constipation, sluggish reflexes, and confusion, whereas too low calcium levels may lead to impaired blood coagulation, skipped heart beats, negative effects on muscle contraction and nerve functioning, and-in the long term-brittle bones.

Due to the physiological importance of (low) constant non bone-calcium levels, total and ionized calcium in serum are tightly maintained within a physiological range of $2.1-2.6 \mathrm{mM}(8.5-10.5 \mathrm{mg} /$ dl) or $1.1-1.35 \mathrm{mM}(4.4-5.4 \mathrm{mg} / \mathrm{dl})$, respectively. This is controlled by PTH (parathyroid hormone), vitamin D metabolites (principally calcitriol $\left(\left(1,25\right.\right.$ dihydroxyvitamin $\left.\mathrm{D}_{3}, 1,25(\mathrm{OH})_{2} \mathrm{D}_{3}\right)$ and other systemic hormones.

\section{Recommendations for calcium intake}

Numerous in vitro and in vivo investigations and clinical studies have undoubtedly proven the essentiality of an adequate calcium supply for bone formation and maintenance as well as maintenance and/or regulation of numerous physiological processes. With this knowledge is an amazing phenomenon that the question of how much calcium is necessary to meet physiological needs and prevent calcium-dependent diseases cannot be definitively answered. Above all, it is still the subject of intense debates whether an increased intake in dietary and/or supplemental calcium above physiological requirements promotes the development of bone mass and reduces the risk of osteoporosis. 
In recentyears the recommended daily allowances for calcium have been re-examined. For nutritional purposes, the FAO/WHO, ${ }^{5}$ the food and nutrition board of the US American Institute of Medicine $(\text { IoM 2011) })^{6}$ and the European Food Safety Authority (EFSA), ${ }^{7}$ as well as various expert groups from many other countries or groups of countries including the German speaking ones (D-A-CH, Deutschland-Austria-Confoederatio Helvetica), ${ }^{8}$ have developed sets of Dietary Reference Values (DRVs; Europe) ) $^{7,9}$ or Dietary Reference Intakes (DRIs; US), ${ }^{6,10}$ respectively. DRVs include the Average Requirements (AR) and the Population Reference Intake (PRI), daily intake levels sufficient to meet the nutrient requirements of $50 \%$ or $97.5 \%$, respectively, of a healthy population. The corresponding DRI values are the Estimated Average Requirements (EAR) and the Recommended Dietary Allowances (RDA).

Further Dietary Allowances include the Lower Threshold Intake (LTI; intake below which nearly all individuals will be unable to maintain metabolic integrity), the (Tolerable) Upper (Intake) Level (UL, which means the maximum daily intake unlikely to cause adverse health effects) and the Adequate Intake (AI), which is established when evidence is insufficient to develop an RDA and is set at a level assumed to ensure nutritional adequacy.

After reviewing a large number of papers on the relationship between dietary calcium and various skeletal and non-skeletal health outcomes, most expert groups and many medical societies came to the conclusion, that due to inconsistent results of often underpowered and inadequately designed studies, there is insufficient evidence from human trials for calcium health effects that might serve as a basis for deriving calcium requirements. ${ }^{7}$

Therefore recommendations for calcium intake are mainly based on balance studies or were derived from factorial approaches, i.e. the sum of calcium required for bone accretion, renal calcium excretion, and fecal and insensible (through skin, nails and hair) calcium losses, multiplied with the percentage of intestinal calcium absorption; (Figure 1), rather than on disease-related clinical or surrogate endpoints ${ }^{11}$ (bone mass, bone mineral density (BMD), bone fractures or osteoporosis).

Some medical societies, whose primary interest is prevention or treatment of osteoporosis, justify their (usually higher) recommendations for calcium intake with clinical studies and metaanalyzes, in which an increased calcium intake above the physiological requirements did contribute to increased BMD and/or a reduced risk of osteoporosis.

Table 1 provides as an example calcium recommendations and intake data for Germany, the EU and the USA. The DRIs in the EU, $7,12,13$ including the German speaking countries (D-A-CH 2015) ${ }^{8}$ and the DRVs of the US Institute of Medicine (IoM 2011), ${ }^{6}$ were calculated for growing subjects (children and adolescents from 1 through $<19$ years)) by factorial approaches that sum up calcium accretion (from 90 to $210 \mathrm{mg} / \mathrm{d}$ ) and obligatory calcium losses (between -70 and $-290 \mathrm{mg} / \mathrm{d}$ ), multiplied by fractional absorption $(46 \%-38 \%){ }^{14-18}$

For adults ( $\geq 19$ years of age) calcium intake to achieve calcium balance was used, showing zero balance at an average calcium intake of $741 \mathrm{mg} /$ day. ${ }^{19}$ Due to the lack of usable research results for infants $<12$ month, AIs were derived by extrapolating upwards calcium intake data from exclusively breast-fed babies. ${ }^{20}$ Moreover, in the EFSA recommendations, a PRI of $950 \mathrm{mg} /$ day is set for all adults, because the expert group found no clear evidence for beneficial effects of a higher calcium intake on postmenopausal bone loss or the fracture risk in elderly subjects ( $>65$ years). By contrast, the IOM committee increased the RDA values for women $>50$ and men $\geq 70$ years to $1200 \mathrm{mg} /$ day to reduce bone loss. ${ }^{21-23}$

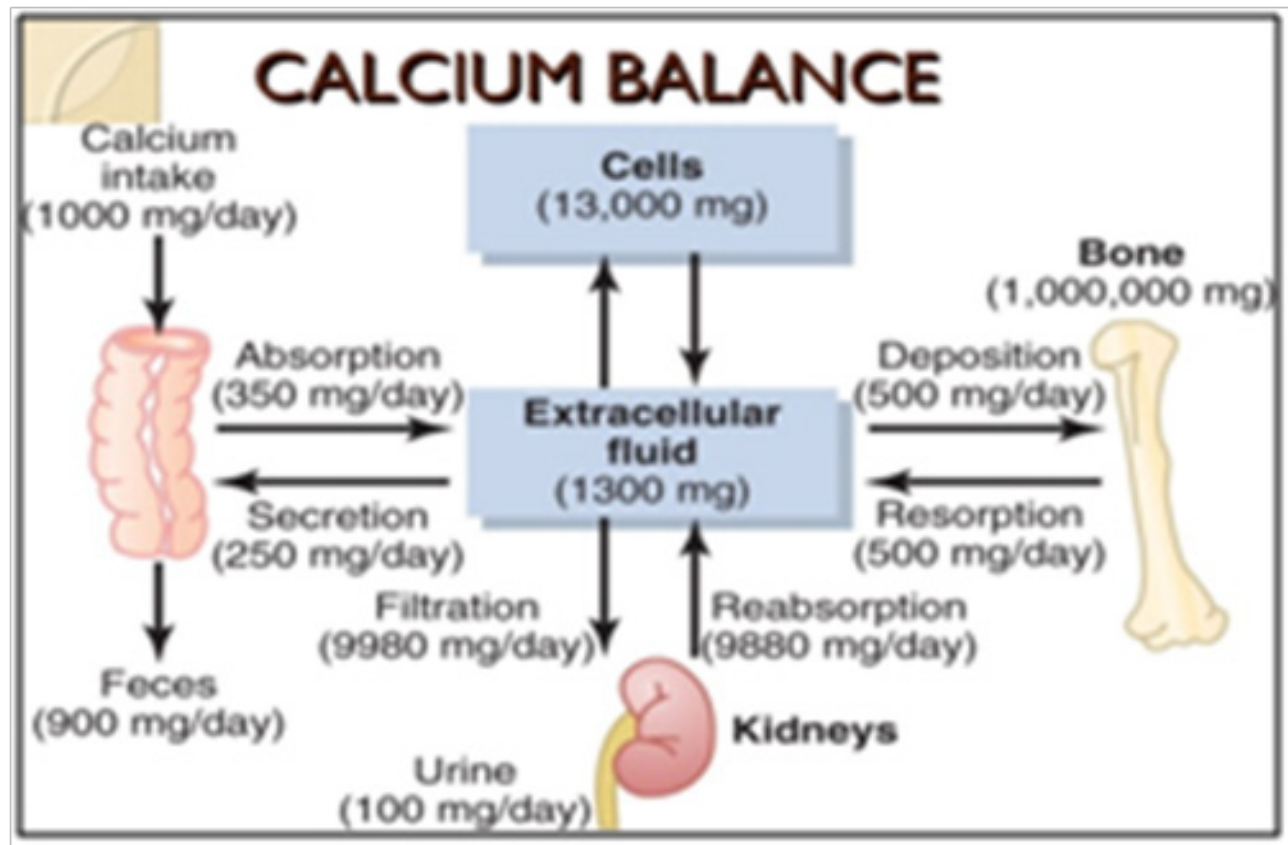

Figure I Calcium fluxes between the different compartments of the body in healthy adult subjects consuming a protein-rich, western-style"diet. Apparent Ca absorption (= Ca intake - fecal excretion) and true Ca absorption (= Ca intake - [fecal excretion - endogenous Ca secretion]) are $100 \mathrm{mg} / \mathrm{d}(10 \%)$ or $350 \mathrm{mg} / \mathrm{d}$ (35\%), respectively. 
Table I Calcium recommendations and intake data for Germany, the EU (mean of 4 to 8 selected countries) and the USA. Intake data for Germany are from the VELSI study (children <3 y), the EsKiMo2 study (children and adolescents 3-> I 9 y) and the NVS-24 h recall3 (adults I9-80 y). Tolerable Upper Intake Level (UL) of calcium from all sources (dietary and supplemental) in Europe and Germany are (EFSA 2003): Children and adolescents no recommendations; adults, including pregnant and lactating women $2500 \mathrm{mg} / \mathrm{d}$, the corresponding US-values (IoM 20I0) are: infants, children and adolescents 0-0.5/0.5-I/I-8/9-I8years: I,000/I,500/2,500/3,000mg/d; adults $19-50 />50$ y: 2,500/2,000mg/d; pregnant and lactating women $</>19$ y: 3,000/2500mg/d

\begin{tabular}{|c|c|c|c|c|c|c|c|c|c|c|c|c|c|c|c|c|c|}
\hline \multicolumn{3}{|c|}{$\begin{array}{l}\text { EFSA } \\
\text { Recommendations }\end{array}$} & \multicolumn{4}{|c|}{ Calcium Intake Germany } & \multicolumn{4}{|c|}{ Calcium Intake EU } & \multicolumn{3}{|c|}{$\begin{array}{l}\text { US } \\
\text { Recommendations }\end{array}$} & \multicolumn{4}{|c|}{ Calcium Intake USA } \\
\hline \multirow{2}{*}{$\begin{array}{l}\text { Age } \\
\text { Years }\end{array}$} & \multirow{2}{*}{$\begin{array}{l}\text { AR } \\
\mathrm{mg} / \mathrm{d}\end{array}$} & \multirow{2}{*}{$\begin{array}{l}\text { PRI } \\
\mathrm{mg} / \mathrm{d}\end{array}$} & \multirow{2}{*}{$\begin{array}{l}\text { Age } \\
\text { years }\end{array}$} & \multirow{2}{*}{$\begin{array}{l}\text { Intake } \\
\mathrm{mg} / \mathrm{d}\end{array}$} & \multicolumn{2}{|c|}{$\begin{array}{l}\text { \%Fulfillment } \\
\text { of demand }\end{array}$} & \multirow{2}{*}{$\begin{array}{l}\text { Age } \\
\text { years }\end{array}$} & \multirow{2}{*}{$\begin{array}{l}\text { Intake } \\
\mathrm{mg} / \mathrm{d}\end{array}$} & \multicolumn{2}{|c|}{$\begin{array}{l}\text { \%Fulfillment } \\
\text { of demand }\end{array}$} & \multirow{2}{*}{$\begin{array}{l}\text { Age } \\
\text { years }\end{array}$} & \multirow{2}{*}{$\begin{array}{l}\text { EAR } \\
\mathrm{mg} / \mathrm{d}\end{array}$} & \multirow{2}{*}{$\begin{array}{l}\text { RDA } \\
\mathrm{mg} / \mathrm{d}\end{array}$} & \multirow{2}{*}{$\begin{array}{c}\text { Intake } \\
\text { years }\end{array}$} & \multicolumn{3}{|c|}{ \%Fulfillment of demand ${ }^{4}$} \\
\hline & & & & & & & & & & & & & & & $\mathrm{mg} / \mathrm{d}$ & & \\
\hline$<1$ & & 280 & $<1$ & $\begin{array}{l}3: 431 \\
0: 377\end{array}$ & $\begin{array}{l}>>50 \\
>50\end{array}$ & $\begin{array}{l}\sqrt{ } \\
\sqrt{ }\end{array}$ & $<1$ & $\begin{array}{l}3: 507 \\
: 450\end{array}$ & $\begin{array}{l}>>50 \\
>>50\end{array}$ & $\begin{array}{l}\sqrt{ } \sqrt{ } \\
\sqrt{ }\end{array}$ & $<1$ & & $\begin{array}{l}210- \\
260\end{array}$ & & & & \\
\hline $1-<3$ & 390 & 450 & $1-<3$ & $\begin{array}{l}3: 568 \\
\delta: 502\end{array}$ & $\begin{array}{l}>>50 \\
>50\end{array}$ & $\begin{array}{l}\sqrt{ } \\
\sqrt{ }\end{array}$ & $1-<3$ & $\begin{array}{l}3: 737 \\
: 664\end{array}$ & $\begin{array}{l}>>50 \\
>>50\end{array}$ & $\begin{array}{l}\sqrt{ } \sqrt{ } \\
\sqrt{ } \sqrt{2}\end{array}$ & $1-3$ & 500 & 700 & $<6$ & $\begin{array}{l}0: 809 \\
0: 708\end{array}$ & $\begin{array}{l}>>50 \\
\pm 50\end{array}$ & $\begin{array}{l}\sqrt{ } \sqrt{ } \\
\sqrt{ } \sqrt{ }\end{array}$ \\
\hline $3-<10$ & 680 & 800 & $3-10$ & $\begin{array}{l}3: 743 \\
: 681\end{array}$ & $\begin{array}{l}>50 \\
\pm 50\end{array}$ & $\begin{array}{l}\sqrt{ } \\
\sqrt{ }\end{array}$ & $3-<10$ & $\begin{array}{l}7: 801 \\
: 745\end{array}$ & $\begin{array}{l} \pm 50 \\
>50\end{array}$ & $\begin{array}{l}\sqrt{ } \sqrt{ } \\
\sqrt{ }\end{array}$ & $4-8$ & 800 & 1000 & $6-11$ & $\begin{array}{l}1: 843 \\
: 812\end{array}$ & $\begin{array}{l}<50 \\
<50\end{array}$ & $\begin{array}{l}\sqrt{ } \\
\sqrt{ }\end{array}$ \\
\hline $10-<18$ & 960 & 1150 & $10-18$ & $\begin{array}{l}\delta: 775 \\
\delta: 751\end{array}$ & & $\begin{array}{l}- \\
-\end{array}$ & $\begin{array}{l}10- \\
<18\end{array}$ & $\begin{array}{l}\delta: 868 \\
\delta: 763\end{array}$ & & - & $9-18$ & 1100 & 1300 & $\begin{array}{l}12- \\
19\end{array}$ & $\begin{array}{l}3: 956 \\
: 661\end{array}$ & & $\begin{array}{l}- \\
-\end{array}$ \\
\hline $18-<24$ & 860 & 1000 & $19-<25$ & $\begin{array}{l}3: 857 \\
\delta: 740\end{array}$ & \pm 50 & $\begin{array}{l}\sqrt{ } \\
-\end{array}$ & $\begin{array}{l}18- \\
<65\end{array}$ & $\begin{array}{l}7: 937 \\
: 800\end{array}$ & $\begin{array}{l}>50 \\
\pm 50\end{array}$ & $\begin{array}{l}\sqrt{ } \\
\sqrt{ }\end{array}$ & $\begin{array}{l}19 \\
-50\end{array}$ & 800 & 1000 & $\begin{array}{l}20- \\
39\end{array}$ & $\begin{array}{l}0 \\
: 856 \\
: 684\end{array}$ & $>50$ & $\begin{array}{l}\sqrt{ } \\
-\end{array}$ \\
\hline \multirow[t]{4}{*}{$\geq 25$} & 750 & 950 & $25-<35$ & $\begin{array}{l}3: 886 \\
: 776\end{array}$ & $\begin{array}{l}>>50 \\
\pm 50\end{array}$ & $\begin{array}{l}\sqrt{ } \\
\sqrt{ }\end{array}$ & $\begin{array}{l}65- \\
<75\end{array}$ & $\begin{array}{l}0: 896 \\
0: 786\end{array}$ & $\begin{array}{l}>>50 \\
\pm 50\end{array}$ & $\begin{array}{l}\sqrt{ } \\
\sqrt{ }\end{array}$ & $\begin{array}{l}51 \\
-70\end{array}$ & $\begin{array}{l}3: \\
800 \\
0: \\
1000\end{array}$ & $\begin{array}{l}3: \\
1000 \\
0: \\
1200\end{array}$ & $\begin{array}{l}40- \\
59\end{array}$ & $\begin{array}{l}\delta: 834 \\
\delta: 621\end{array}$ & $>50$ & - \\
\hline & & & $35-<51$ & $\begin{array}{l}0: 838 \\
: 771\end{array}$ & $\begin{array}{l}>50 \\
\pm 50\end{array}$ & $\begin{array}{l}\sqrt{ } \\
\sqrt{ }\end{array}$ & $\geq 75$ & $\begin{array}{l}0: 850 \\
: 810\end{array}$ & $\begin{array}{l}>>50 \\
>50\end{array}$ & $\begin{array}{l}\sqrt{ } \\
\sqrt{ }\end{array}$ & $\geq 70$ & 1000 & 1200 & $\geq 60$ & $\begin{array}{l}0 \\
: 716 \\
: 563\end{array}$ & & - \\
\hline & & & $51-<65$ & $\begin{array}{l}7: 782 \\
\delta: 726\end{array}$ & $\begin{array}{l} \pm 50 \\
<50\end{array}$ & $\begin{array}{l}\sqrt{ } \\
\sqrt{ }\end{array}$ & & & & & & & & & & & \\
\hline & & & $65-80$ & $\begin{array}{l}\delta: 725 \\
\delta: 683\end{array}$ & $<50$ & $\begin{array}{l}\sqrt{ } \\
-\end{array}$ & & & & & & & & & & & \\
\hline
\end{tabular}

\section{Calcium intake from dietary sources}

A detailed analysis of the data in Table 1, which takes into account the statistical distribution of individual calcium requirements and calcium absorption shows, that in Germany, the EU and the USA and thus (potentially) generally in developed countries, only infants and children under 3years and perhaps boys between 3 and 10years of age are optimally supplied with calcium. By contrast, calcium supply of $\geq 50 \%$ of the adult population in the EU, of $>50 \%$ of men aged between 20 and 59, and of less than $50 \%$ of 6 to 11 years old children in the United States just reaches Average Intake Requirements ((E) $\mathrm{AI})$.

A particular risk for an inadequate supply of calcium exists in times of increased demand (i.e. during skeletal growth), or during age-related reduced nutrient and therefore calcium intake. This means, that children aged between 10 (or 12) and 19years, as well as women over 19 (in the US) or women aged between 19 and 25 and over 65years (in Germany) are groups at risk.
Populations with increased risk also include physically active girls and women participating in sports that emphasize leanness or low body weight (such as ballet, gymnastics and others), a recent metaanalysis showed up to $60 \%$ had at least one symptom of the female athlete triad (disordered eating, amenorrhea, and osteoporosis). ${ }^{24}$ Increased calcium requirements (due to increased bone remodelling) and decreased calcium intake and absorption (resulting from a too low energy and food consumption, and therefore menstrual dysfunction and low estrogens levels) may put the athlete at an increased risk of developing low BMD and osteoporosis, so that to a certain extent, administration of calcium supplements may be helpful, particularly in those athletes with ongoing low consumption of calcium-rich foods. ${ }^{25}$

Other risk factors for a too low calcium intake include

a. Milk avoidance, because (at least) in developed western countries, about $60 \%$ of dietary calcium comes from milk, cheese and fermented milk products. The milk consumption tendency is falling, ${ }^{26}$ and in most studies vegans have a lower calcium 
intake compared with lacto-(ovo-) vegetarians and omnivores..$^{27,28}$

b. (Animal) Proteins, which increase renal calcium excretion through oxidative degradation of sulfur-containing amino acids to sulphate ions, which have to be excreted via the kidneys (each gram of protein takes out $1 \mathrm{mg}$ calcium). ${ }^{29,30}$ On the other hand, proteins are essential components of the bone matrix, and certain (milk) proteins and peptides increase intestinal calcium absorption, at least under experimental conditions. ${ }^{31}$ Therefore elderly people, and particularly hospitalized elderly ones, where malnutrition and protein deficiency are common, are at increased risk of hip fractures, whereas optimal protein intake decreased that risk. ${ }^{32-34} \mathrm{All}$ in all, these findings suggest, that, when calcium intake is adequate or high, increased protein consumption is not a risk for bone health, ${ }^{35}$ and in a recent meta-analysis of 35 studies, the authors came to the conclusion, that a dietary acid load (from animal protein) and the resulting increase in renal calcium excretion do not cause osteoporosis ${ }^{36}$ again provided an adequate calcium intake. Accordingly, in the dietary recommendations for "western" countries, the high consumption of (animal) protein in the "western style" diet is taken into account by corresponding high RDI values for calcium and vitamin D (see section 2.2).

c. Phosphorus, which (in the form of phosphate) plays an ambivalent role in calcium balance and bone formation. It is a major component of bones and teeth and reduces the calciuric effect of excess protein. ${ }^{37}$ On the other hand, phosphorus stimulates PTH secretion and increases fecal calcium losses, but this possibly impairs bone health only if at the same time calcium intake is low.

d. Sodium, which impairs calcium balance by increasing serum PTH and decreasing calcium reabsorption in the kidney tubules: an extra dose of $100 \mathrm{mmol} \mathrm{Na}(6.3 \mathrm{~g} \mathrm{NaCl})$ takes out $0.5-1 \mathrm{mmol}$ calcium, and, when consumed daily, may cause annual bone losses of $1 \%$ in women, as excreted calcium has been mobilized from bones. $^{38-40}$

e. Ant nutritive food components from plants, which reduce intestinal calcium absorption by forming poorly soluble calcium compounds (particularly oxalic acid, ${ }^{41}$ phytic acid, ${ }^{42}$ tannins from coffee or tea, and some types of dietary fiber) ${ }^{43}$ or increase renal calcium excretion (e.g. caffeine $\mathrm{e}^{44}$ ). However, their detrimental effects on calcium absorption are much lesser when ingested in or together with other foods. . $^{42,45,46}$

Nevertheless, it should be kept in mind that an average content of dietary fiber and "ant nutritive" factors and the high percentage of animal protein or phosphate in the "Western-style" diet have already been considered when DVRs/DVIs were calculated.

\section{TCC and other calcium compounds for food fortification and as dietary supplements}

In the last three decades there has been a substantial expansion of sales of calcium for use as supplements and in food fortification. This also raises the question for the most suitable preparations in terms of price, calcium content, and calcium bioavailability, scientifically proven health effects, side effects and consumer compliance.

\section{Formes of calcium}

Several formes of calcium are available: inorganic salts (such as calcium carbonate $\left(\mathrm{CaCO}_{3}\right)$, calcium phosphate $\left(\mathrm{Ca}_{3}\left(\mathrm{PO}_{4}\right)_{2}\right)$ or calcium chloride $\left.\left(\mathrm{CaCl}_{2}\right)\right)$ and organic salts with either $\mathrm{Ca}^{2+}$ or calcium (chelate) complexes as cations (e.g. Tricalcium Dicitrate*4 $\mathrm{H}_{2} \mathrm{O}$ (TCC)). There are also calcium supplements from animal or vegetable origin, of which the composition is less well defined, such as milk calcium (comprised mainly of calcium phosphates and caseinates plus small amounts of the citrate), or oyster shell and sea weed calcium (comprised mainly of $\mathrm{CaCO}_{3}$ ), which however have an at least comparable bioavailability. ${ }^{47}$ In all classes, there are (practically) insoluble, moderately soluble and highly water-soluble compounds.

However, solubility and bioavailability depend not only on the chemical composition of the calcium compound, but also on its particle size and of the dosage form. For example, in mice "nano" $\mathrm{CaCO}_{3}$ and "nano" TCC (mean particle sizes $151 \pm 19 / 398 \pm 4 \mathrm{~nm}$ ) were more bioavailable than the corresponding "micro" compounds (particle sizes $3773 \pm 759 / 1793 \pm 382 \mathrm{~nm}),{ }^{48}$ whereas administration of calcium supplements in the form of firmly pressed tablets seems to reduce its bioavailability compared to a powdered calcium supplement. ${ }^{49}$

An overview of the top 5 commercially used and approved calcium salts for use in food, beverages or dietary supplements globally is given in Table $2 .{ }^{50}$ Of these, $\mathrm{CaCO}_{3}, \mathrm{TCC}$ and calcium phosphates are the most widely used with a $93 \%$ share of products launched recently in dietary supplements and $89 \%$ in food and beverages.

Table 2: Top 5 calcium salts used in dietary supplements and food \& beverages and related main market categories. ${ }^{50}$ Search was based on product launch count 2014-16 globally in the www.innovadatabase. com database on 18.07.2017. To focus on the nutritional use of calcium salts, search was done in the ingredients list of products launched globally in the period 2014-2016 for those products which had "calcium" in the product brand for bone health supplements and which were positioned as "added calcium" for fortified food \& beverage products.

\section{Compliance of calcium supplements and especially of TCC}

Water solubility, absorbability and the concentration of calcium are regarded as the most important quality criteria for calcium supplements in order to meet recommended intakes. In view of positive health effects such as to increase BMD and to reduce risk of osteoporosis and bone fractures, compliance of a calcium preparation is at least as important. This was demonstrated impressively in a meta-analysis of studies on the effect of calcium with or without vitamin D on osteoporotic bone loss and fractures, ${ }^{51}$ in which fracture risk reduction was significantly greater $(24 \%)$ in trials in which the compliance rate was high $(\mathrm{p}<0.0001)$. Compliance of TCC is thought to be high because of the lack of potential side effects, the neutral taste and the intermediate calcium content, because a high calcium content may on the one hand increase compliance by decreasing the frequency of supplement intake, but on the other hand it increases the risk of side effects and thereby reduces compliance, it impairs calcium absorption and increases potential risks of sharp fluctuations in serum calcium levels.

\section{Intestinal absorption of calcium compounds}

In addition to cost, calcium content and compliance, bioavailability of a calcium compound (that means its absorption, retention and adequate use in the body) is the most important quality criterion with respect to supplementation and food fortification. Bioavailability of a calcium compound is often equated with its solubility in water, because calcium is absorbed only in the dissolved state. 
Calcium ions are absorbed in the intestinal mucosa by two distinct routes - a passive, diffusion-driven, and non-saturable transport through the tight junctions between mucosa cells and a vitamin $\mathrm{D}_{3}$ dependend active, transcellular, saturable transport. ${ }^{52-54}$ Passive par cellular transport occurs with moderate activity throughout the length of the intestine, driven by the luminal: serosal concentration gradient of $\mathrm{Ca}^{2+}$ ions.

Table 2 Top 5 calcium salts used in dietary supplements and food \& beverages and related main market categories. ${ }^{50}$ Search was based on product launch count 2014-16 globally in the www.innovadatabase.com database on 18.07.2017. To focus on the nutritional use of calcium salts, search was done in the ingredients list of products launched globally in the period 2014-2016 for those products which had "calcium" in the product brand for bone health supplements and which were positioned as "added calcium" for fortified food \& beverage products

\begin{tabular}{|c|c|c|c|c|c|}
\hline \multirow[t]{2}{*}{ Ca Salt } & \multirow[t]{2}{*}{$\begin{array}{l}\text { Ca } \\
\text { Content }\end{array}$} & \multirow{2}{*}{$\begin{array}{l}\text { Solubility (g/L } \\
\left.\mathrm{H}_{2} \mathrm{O}, \mathrm{RT}\right)\end{array}$} & \multirow{2}{*}{$\begin{array}{l}\text { Main Market Category } \\
\text { (Descending Order) }\end{array}$} & \multicolumn{2}{|c|}{ Share of Products Launched } \\
\hline & & & & Dietary Supplements' & Food \& Beverages ${ }^{2}$ \\
\hline Ca Carbonate & $40 \%$ & Insoluble & $\begin{array}{l}\text { Dietary supplements, dairy, baby \& } \\
\text { toddlers food, cereals }\end{array}$ & $58.40 \%$ & $41.00 \%$ \\
\hline Ca Citrate (TCC) & $21 \%$ & 0.9 & $\begin{array}{l}\text { Dairy, dietary supplements, baby \& } \\
\text { toddlers food }\end{array}$ & $20.70 \%$ & $11.10 \%$ \\
\hline Ca Phosphates & $17-36 \%$ & $\begin{array}{l}\text { Slightly soluble to } \\
\text { insoluble }\end{array}$ & $\begin{array}{l}\text { Dairy, baby \& toddlers food, dietary } \\
\text { supplements, cereals }\end{array}$ & $14.10 \%$ & $36.90 \%$ \\
\hline $\mathrm{Ca}$ Gluconate $* \mathrm{H}_{2} \mathrm{O}$ & $9 \%$ & 3.5 & Dietary supplements & $2.80 \%$ & $0.60 \%$ \\
\hline Ca Lactate $* 5 \mathrm{H}_{2} \mathrm{O}$ & $13 \%$ & 66 & Soft drinks, dairy & $2.40 \%$ & $5.90 \%$ \\
\hline
\end{tabular}

Active transcellular calcium absorption in the intestine is a multistep process, which comprises a) uptake of calcium ions across the apical plasma membrane via the calcium-channel protein TRPV b) transcellular transport of $\mathrm{Ca}^{2+}$-ions by calbindin (Ca BP, calciumbinding protein) and c) extrusion of calcium from the enterocytes into the circulation. All steps are controlled by active vitamin D3. ${ }^{55}$

The saturable calcium transport predominates at low calcium concentrations in the chyme. At high $\mathrm{Ca}^{2+}$-concentrations, however, in segments of the intestine (ileum) with a low efficacy of the saturable component or in neonates and infants (in which this component has not yet been fully developed), calcium absorption occurs predominantly by passive transport. However there are different opinions: while some authors came to the conclusion that at high, but still physiological calcium concentrations intestinal absorption by passive transport exceeds the active component, ${ }^{56}$ other authors state that under all conditions passive transport plays only a minor role. ${ }^{57}$

Differential absorption kinetics of calcium from food or from supplements as well as differences between various calcium salts are manifested in earlier and higher rises of serum calcium with supplemental calcium, in a larger total amount of calcium absorbed from food $^{58}$ and significant differences in the time course of increases in serum calcium and reactive decreases in serum PTH (citrate $>$ carbonate) ${ }^{59}$

It is frequently claimed that especially due to a relatively high solubility TCC has a better bioavailability than sparingly soluble calcium salts such as $\mathrm{CaCO}_{3}$.

This needs to be scrutinized for several reasons:

a. Ionic TCC is indeed poorly soluble in water at $18^{\circ} \mathrm{C}(850 \mathrm{mg} / \mathrm{l})$. By comparison, the aqueous solubility of $\mathrm{CaCO}_{3}$ is $14 \mathrm{mg} / 1$ at $20^{\circ} \mathrm{C}$. However, the comparison of the solubility's of TCC and $\mathrm{CaCO}_{3}$ in pure water is not representative of physiological condition, as an unbuffered TCC solution is acidic ( $\mathrm{pH} 5.6)$, whereas the $\mathrm{CaCO}_{3}$ solution reacts alkaline ( $\mathrm{pH} 8.5)$. b. Solubility of TCC and $\mathrm{CaCO}_{3}$ is $\mathrm{pH}$ dependent. It decreases with increasing $\mathrm{pH}$, that is, from the duodenum $(\mathrm{pH} \sim 6.0)$ and proximal jejunum ( $\mathrm{pH}$ 6.6) up to the terminal ileum ( $\mathrm{pH} 7.5$ ). Below $\mathrm{pH}$ 6.5 (or only below $\mathrm{pH} 7.5$ at atmospheric pCO2; Figure 3), the solubility of ' $\mathrm{CaCO}_{3}$ is greater than that of TCC. Above $\mathrm{pH} 6.6$, that means from the middle of the jejunum, the solubility of TCC exceeds that of $\mathrm{CaCO}_{3} \cdot{ }^{60,61}$

c. Also poorly soluble calcium compounds and calcium complexes such as the water-soluble dicitrato calcium complex (Figure 4) may provide sufficient calcium ions for absorption, because trans- and paracellular calcium absorption are irreversible processes. Therefore the small amount of dissociated $\mathrm{Ca}^{2+}$-ions is permanently removed from the equilibrium, so that dissociation and therefore absorption of calcium ions can continue. This was also demonstrated by investigations in rats, in which calcium was indeed most readily absorbed in the form of $\mathrm{Ca}^{2+}$-ions, but soluble citrate complexes in the duodenum and cecum were absorbed as well. ${ }^{62}$ Moreover, dissociation of poorly soluble calcium compounds, and thus concentration of $\mathrm{Ca}^{2+}$-ions in the mucosa, could be increased by microbial (intestinal micro biota, pro- and Prebiotics) formed acids.

d. With adequate gastric juice production also poorly or moderately soluble calcium compounds like $\mathrm{CaO}, \mathrm{CaCO}_{3}$ or TCC are converted into easily soluble $\mathrm{CaCl}_{2}$ (better said: into $\mathrm{Ca}^{2+}$-and $\mathrm{Cl}^{-}$ ions) by $\mathrm{HCl}$ in the stomach. In the more alkaline environment ( $\mathrm{pH}$ 6-7.5) of the small intestine, $\mathrm{CaCl}_{2}$ is converted back into $\mathrm{CaCO}_{3} / \mathrm{Ca}\left(\mathrm{HCO}_{3}\right)_{2}$ by the bicarbonate ions in the pancreatic juice. Therefore, the solubility of the calcium supplement should have no impact on its intestinal absorption, as has been pointed out in a number of publications. ${ }^{63}$

e. Because of these different and sometimes contradictory influencing factors a superior or at least equal bioavailability of TCC compared to $\mathrm{CaCO}_{3}$ cannot be derived by theoretical considerations, but has to be examined in clinical trials. 


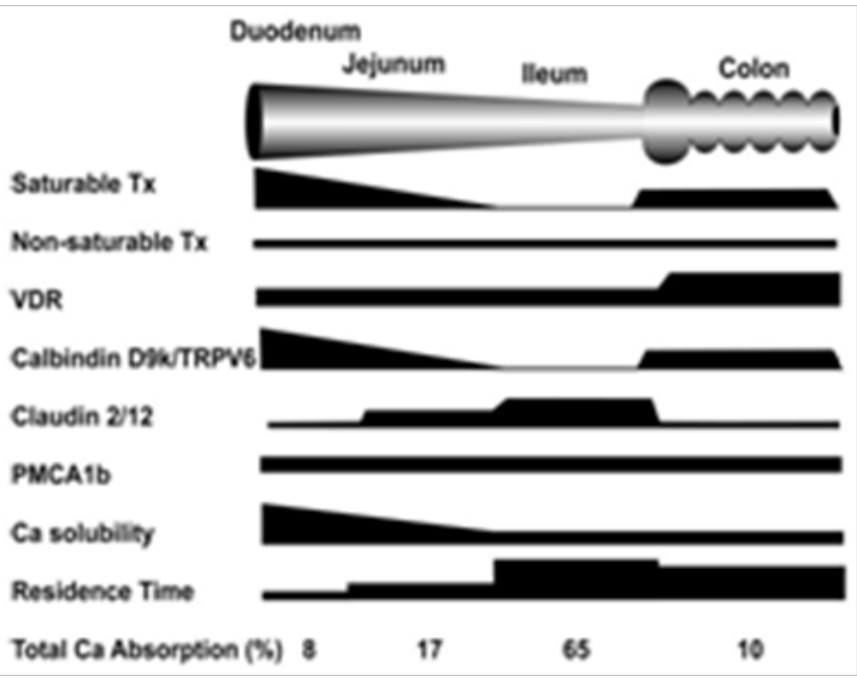

Figure 2 Semi quantitative relations between factors affecting intestinal calcium absorption. ${ }^{51}$

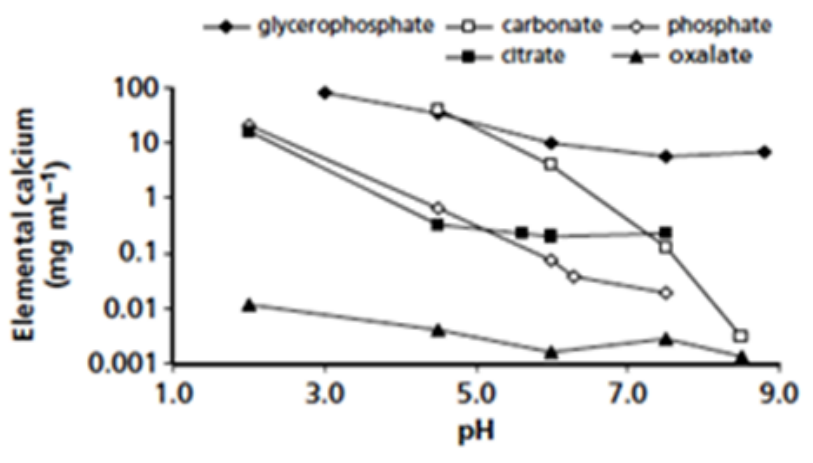

Figure 3 Log solubility plot of calcium salts in aqueous solutions open to the atmosphere. ${ }^{60}$

\section{Bioavailability of $\mathrm{TCC}$ versus $\mathrm{CaCO} 3$ : results from clinical studies}

Absorption and bioavailability of calcium from $\mathrm{CaCO}_{3}$ - and TCC- containing supplements have been studied extensively in a number of randomized, controlled clinical trials, using various target parameters and techniques for their determination.

In these studies, between 200 and $1200 \mathrm{mg} / \mathrm{d}$ of both calcium salts were administered in a cross-over design to healthy men, pre- and postmenopausal women or children, either on an empty stomach or together with a meal.

A meta-analysis of 15 papers published between 1984 and 1999 was performed by ${ }^{64}$ In their paper the authors came to the conclusion that calcium absorption is significantly higher by $20 \%$ after consumption of TCC than after a $\mathrm{CaCO}_{3}$ supplement containing the same amount of calcium. This value increased to $24 \%$ after the authors had eliminated four studies from the analysis due to methodological inadequacies, whereas in the two subgroups, in which the calcium supplements had been administered either with food or on an empty stomach, TCC was better absorbed than the carbonate by 22 or $27 \%$, respectively.

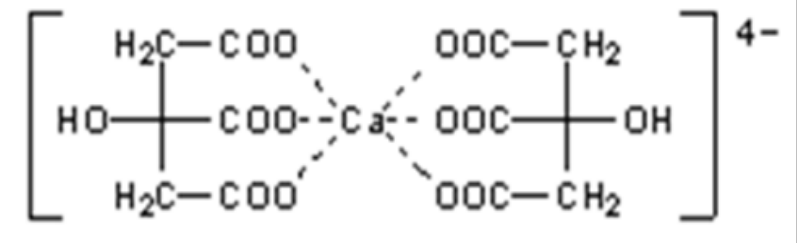

Figure 4 Anionic calcium-dicitrato-complex.

This meta-analysis has sometimes been heavily criticized, because of its great heterogeneity in regard to the study populations, methodology and target parameters. On the other hand, the findings of ${ }^{64}$ were supported by the fact, that in 9 out of 10 comparable more recent studies published from 1996-2009, of which a large part was put together by, ${ }^{65} \mathrm{TCC}$ showed no poorer and in 7 out of 10 even a better absorbability, regardless of whether they had been measured directly or indirectly by measuring bone parameters (Table 3 ). In one of these studies, absorption (measured as increase in serum calcium AUC) of TCC was superior to the carbonate only in estrogen-treated patients or in subjects with higher serum 1.25-dihydroxyvitamin D3 concentrations. ${ }^{81}$ Another study showed superior bioavailability of TCC compared with $\mathrm{CaCO}_{3}$ in obese patients with Roux-en-Y gastric bypass and thereby restricted food intake and impaired calcium absorption. ${ }^{82}$

Table 3 Studies comparing calcium absorption from calcium citrate (generally in form of Tricalcium citrate (TCC)) compared with calcium carbonate (CC)

\begin{tabular}{|c|c|c|c|c|c|}
\hline Authors (Year) & N/Study Subjects' & $\begin{array}{l}\text { Calcium } \\
\text { Mg/D }\end{array}$ & Meal & Method $^{2}$ & $\begin{array}{l}\text { \% Difference } \\
\text { TCCVs. CC }\end{array}$ \\
\hline \multicolumn{6}{|c|}{ Metaanalysis by Sakhaee $(1999)^{3}$} \\
\hline Bo-Linn et al. ${ }^{65}$ & $6 n$ & 1000 & + & L & 21.6 \\
\hline Nicar et al. ${ }^{66}$ & $3 m+11 w$ & 1000 & - & $U$ & 70.5 \\
\hline Recker et al..$^{67}$ & $7 n$ & 250 & - & $S^{*}$ & 8.0 \\
\hline Reid et al. ${ }^{68}$ & $10 n$ & 1000 & + & $U$ & 64.8 \\
\hline Harvey et al. ${ }^{69}$ & $9 n$ & $100 / 200$ & - & $\mathrm{F}$ & 28.0 \\
\hline Sheikh et al..$^{70}$ & $10 n_{y}$ & 1000 & + & L & 4.8 \\
\hline Harvey et al."1 & $20 w$ & 500 & - & $S^{*}$ & 25.8 \\
\hline Harvey et al. ${ }^{69}$ & $4 m+17 w$ & 1000 & - & $U$ & 55.7 \\
\hline
\end{tabular}




\begin{tabular}{|c|c|c|c|c|c|}
\hline Authors (Year) & N/Study Subjects' & $\begin{array}{l}\text { Calcium } \\
\text { Mg/D }\end{array}$ & Meal & Method $^{2}$ & $\begin{array}{l}\text { \% Difference } \\
\text { TCCVs. CC }\end{array}$ \\
\hline \multicolumn{6}{|c|}{ Metaanalysis by Sakhaee $(1999)^{3}$} \\
\hline Heaney et al..$^{72}$ & $17 w$ & 300 & + & $S^{*}$ & 10.8 \\
\hline \multicolumn{6}{|c|}{ Papers added by van der Velde (2014) } \\
\hline Micheletti et al. ${ }^{73}$ & 14 & 1000 & - & $S^{*}$ & Citrate $<$ Carbonate \\
\hline Heller et al. ${ }^{74}$ & $18 w_{p m}$ & 500 & + & S & Citrate $>$ Carbonate \\
\hline Heller et al..$^{75}$ & $25 w_{p m}$ & 500 & + & $\mathrm{S}, \mathrm{U}, \mathrm{P}$ & $46-94$ \\
\hline Heaney et al. ${ }^{76}$ & $24 w_{p m}$ & 200 & + & S, U.P & Citrate $\sim$ Carbonate $(\mathrm{ns})$ \\
\hline Kenny et al..$^{77}$ & $34 w$ & 1000 & + & $\mathrm{U}, \mathrm{P}, \mathrm{X}$ & Citrate $>$ Carbonate \\
\hline Hanzlik et al. ${ }^{59}$ & $14 w$ & 1200 & - & $S, P$ & Citrate $>$ Carbonate \\
\hline Thomas et al..$^{78}$ & $25 w_{p m}$ & $500 / 1000$ & - & $\mathrm{P}, \mathrm{X}$ & Citrate $>$ Carbonate \\
\hline Karp et al. ${ }^{79}$ & $12 w$ & 1000 & + & $S, P$ & Citrate $\sim$ Carbonate $(\mathrm{ns})$ \\
\hline \multicolumn{6}{|c|}{ Supplemental papers } \\
\hline Heller et al..$^{80}$ & $25 w_{p m}$ & 500 & + & $S$ & $242.4^{4}$ \\
\hline Tondapu et al. ${ }^{81}$ & $18 n^{5}$ & 500 & + & $S, U, P$ & 1.9 \\
\hline
\end{tabular}

${ }^{\prime} \mathrm{n} / \mathrm{n}_{\mathrm{y}}$, (normal) Subjects/Young Subjects; $\mathrm{m} / \mathrm{w} / \mathrm{w}_{\mathrm{pm}}$, Men/Women/Postmenopausal Women;

${ }^{2}$ L, lavage; S/S*, Unlabeled/Labelled Serum Calcium (AUC or peak); F/U, Fecal/Urinary Calcium;

P, PTH; X, CTX/NTX bone resorption marker

${ }^{3}$ Of the II "valid" studies of Sakhaee et al., ${ }^{64}$ two further studies were removed in the present table, in which

the calcium citrate malate complex had been in used in place of calcium citrate

${ }^{4}$ Only in non-estrogen-treated patients or in subjects with higher serum I,25-dihydroxyvitamin $D_{3}$

${ }^{5}$ Obese patients with restricted food intake and impaired calcium absorption due to gastric bypass

\section{Other effects}

Furthermore, often mentioned advantages of TCC compared to $\mathrm{CaCO}_{3}$ are the following:

a. For optimum absorption and bioavailability, $\mathrm{CaCO}_{3}$ but not TCC requires gastric acid. Therefore, and particularly when not administered as part of a meal, $\mathrm{CaCO}_{3}$ may not be the best supplement in achlorhydric subjects, in elderly people with impaired gastric acid production or in patients using gastric acid inhibitors. $^{67}$

b. Dissolution of $\mathrm{CaCO}_{3}$ but not of TCC in the stomach is associated with the release of gaseous $\mathrm{CO}_{2}(\sim 0.51$ per $1000 \mathrm{mg}$ carbonate) which may cause some discomfort in sensitive people.

c. In response to the neutralization of gastric acid by $\mathrm{CaCO}_{3}$, calcium carbonate (but not the citrate) can cause rebound hyperacidity, i.e. the stomach overcompensates for the high dose of alkaline calcium carbonate by the secretion of more acid. ${ }^{83}$

d. Other side effects, which are attributed rather to calcium carbonate than to the citrate, are $\mathrm{CaCO}_{3}$ gallstones $(5-30 \%$ of all gallstones in adults and $25 \%$ in children are $\mathrm{CaCO}_{3}$ gallstones) ${ }^{84}$ and a condition that is called the calcium-alkali syndrome (CAS; see section 6.2.).

\section{Positive health effects of calcium and particularly TCC}

The next two paragraphs cannot be restricted to TCC, because after exposure to gastric acid and pancreatic juice and due to the absorption mechanism, calcium is absorbed in the form of soluble ions, regardless of the administration form. Additional effects of counter ions and/or components of the food matrix must be distinguished from the actual calcium effect. Or in other words, results that were obtained with TCC, provide part of the overall evidence for positive and negative health effects of calcium, while, conversely, results which have been obtained with any (absorbable) calcium compounds, are in general also true for TCC, at least qualitatively.

In addition, most of the studies, in which TCC was used as the supplement, were not specifically designed for the investigation of TCC, but because the citrate is one of the most commonly used calcium salts.

\section{Bone and skeletal health}

There is no doubt, that calcium and vitamin $\mathrm{D}$ are indispensable for maintaining bone mineral density/content (BMD/BMC) and bone health. There is, however, much debate, whether an adequate or even increased intake of dietary and supplemental calcium with or without vitamin $\mathrm{D}$ increases bone mass and bone stability in adolescence and 
adulthood and thus reduces bone loss and the risk of osteoporosis later in life and particularly in postmenopausal women.

Clinical studies and meta-analyses on the effects of calcium supplementation with or without vitamin D on bone mineral density (BMD) or fractures rates have conflicting results, depending on the duration of the intervention, the observation period, the type of bone and the population group studied: the general population, children, pre- or postmenopausal women, or non-institutionalized or institutionalized elderly. Equally important is the choice of an appropriate study endpoint, because, for example, modest improvements in BMD are not accompanied by reduction of bone fracture rates. ${ }^{85}$

Whereas in some studies calcium supplements with or without vitamin $\mathrm{D}$ were associated with a moderate reduction in bone $\operatorname{loss}^{51,86,87}$ and fractures, ${ }^{51,88}$ other investigators found no or only marginal differences in fracture rates between subjects taking calcium with or without vitamin $\mathrm{D}_{3}$ or placebo. ${ }^{86,89,90}$ In a meta-analysis by, ${ }^{85}$ hip fracture risk was marginally reduced by $8 \%$ (RR 0.92$)$ with increased calcium intake from 800 to $1600 \mathrm{mg}$.

In healthy children, calcium has a moderate positive effect on total body BMC and upper limb BMD, being, however, unlikely to reduce fracture risk later in life. ${ }^{91}$

In elderly (postmenopausal) women with too low calcium consumption, the (longer-term) increase in calcium intake by means of TCC reduced bone resorption and stabilized BMD, possibly by suppressing increased PTH levels. The frequency of fractures was not investigated..$^{92-95}$

Fracture risk reduction was significantly greater a) in institutionalized subjects over $70 y^{-a r s^{52,96-98}}$ and with low body weight, ${ }^{52}$ b) among study participants with a high compliance ${ }^{51}$ and, because of the slowness of calcium effects on bones - c) in trials where calcium administration was continued and observed over a long period $(>5$ y). This was demonstrated in the Women's Health Initiative“, 98,99 a study in 36282 women, which received $1000 \mathrm{mg} / \mathrm{d}$ carbonate plus 400 IU/d vitamin D or placebo over seven years (Figure 5). ${ }^{100}$
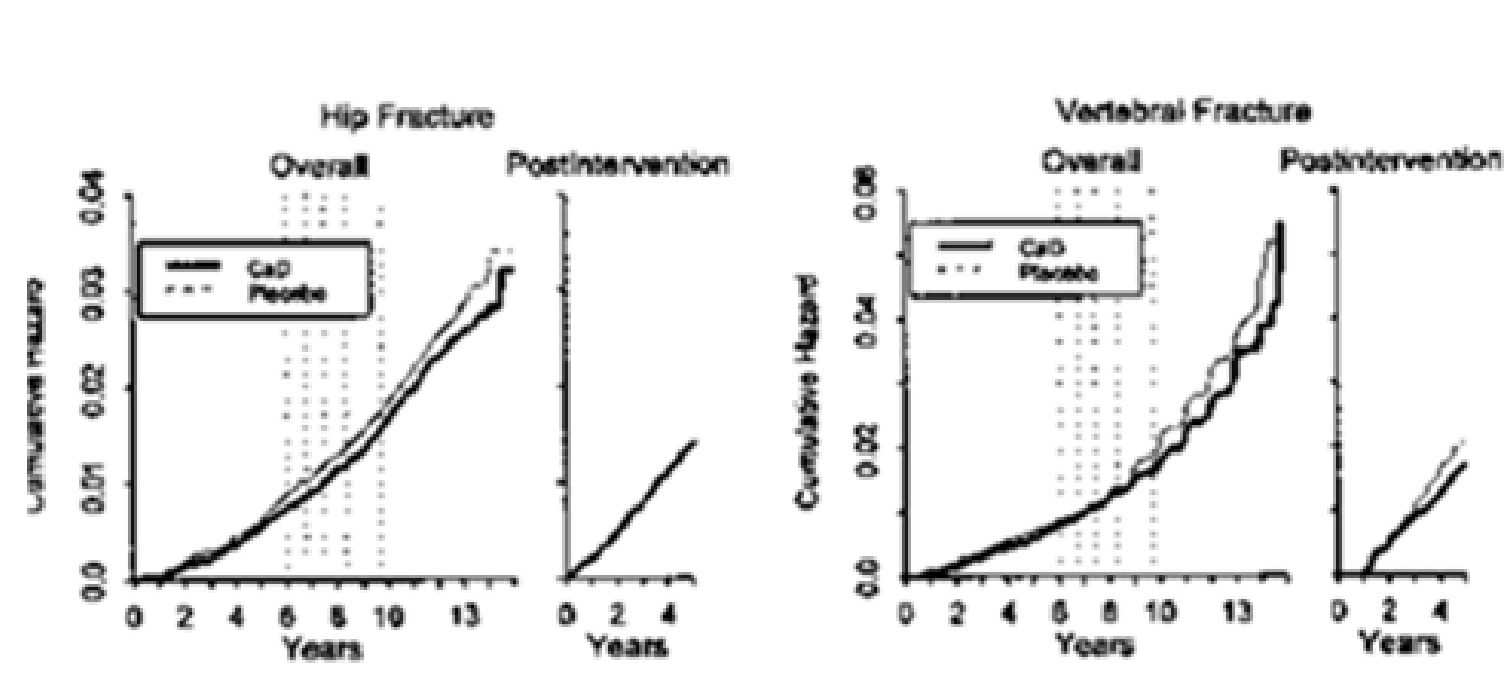

Figure 5 Effect of daily supplementation with $1000 \mathrm{mg}$ calcium plus $400 \mathrm{UU}$ vitamin D in the Women's Health Initiative (WHI) CaD supplementation trial on cumulative hip and vertebral fracture risk during 7years intervention and 7years follow-up. ${ }^{99}$

\section{Obesity and the metabolic syndrome}

In a number of (mainly epidemiological) studies an inverse association between dietary or supplemental calcium and the cluster of metabolic disorders that is termed the metabolic syndrome has been demonstrated, particularly between calcium and obesity, ${ }^{101-103}$ insulin resistance, ${ }^{104-106}$ hypertension, ${ }^{107}$ dyslipidemia and obesity-associated low-grade inflammation. ${ }^{108-110}$ These effects may be partly explained by increased fecal lipid (and energy) loss and sterol excretion through the formation of poorly soluble fatty acid soaps and bile salts, ${ }^{111}$ by a reduced spontaneous food intake ${ }^{112}$ or, particularly with respect to inflammatory complications, by the vitamin D mediated inverse association between calcium intake and intracellular $\left[\mathrm{Ca}^{2+}\right]$ in adipocytes, ${ }^{113,114}$ or vascular smooth muscle cells. ${ }^{115}$ Due to the low number of high-quality studies and participants on this matter, the measured effects are often weak or inconsistent and the underlying mechanisms are poorly understood, so that no intake recommendations can be derived there from.

\section{Adverse effects}

\section{Kidney stones}

Urinary stone disease is characterized by crystalline depositions (calculi), $80 \%$ of which are calcium oxalate stones with a variable amount of calcium phosphate. Less than $20 \%$ of stones are noncalcium calculi composed out of uric acid, magnesium ammonium phosphate, or cysteine. ${ }^{116}$ However, the question whether a high intake of calcium from/with food and/or from supplements is associated with an increased risk of chronic hypercalciuria, impaired kidney function, and nephrolithiasis is discussed controversially. ${ }^{17}$

It could even be that an efficient calcium absorption (e.g. by the use of vitamin D supplements) and thereby large amounts and a high peak concentration of calcium in the circulation increases the risk of calcium oxalate stones. An example for this is the Women's Health Initiative (WHI) CaD supplementation trial, in which daily supplementation with $1000 \mathrm{mg}$ calcium plus $400 \mathrm{IU}$ vitamin D for 
7 years was associated with an increase in the incidence of selfreported urinary tract stones by $20 \%$ from $2.1 \%$ to $2.5 \%$ (Table 4 ). ${ }^{118}$

By contrast, a high intake of calcium alone (and thus a high concentration of calcium in the gut) could reduce the absorption of dietary oxalic acid in the intestine by formation of insoluble calcium oxalate, whereby the stone risk does not increase or could even be lowered (Table 4).

Moreover, using TCC as the supplement may also reduce the risk of renal stones, due mainly to citrate complexation of calcium and to the enhanced citrate excretion which augments the inhibitory activity against calcium oxalate crystallization (Table 4). ${ }^{119}$

So, the EFSA Panel ${ }^{117}$ notes that calcium intakes up to about 2400 or $3000 \mathrm{mg} / \mathrm{d}$, respectively, have not been associated with an increased risk of impaired kidney function and chronic hypercalciuria, or an increased risk of nephrolithiasis in the adult population. Dietary calcium restriction may lead to bone demineralization and even an increase in stone formation and should not be recommended. ${ }^{120,121}$

\section{Calcium-alkali syndrome}

The term calcium-alkali syndrome (CAS; formerly milk-alkali syndrome) refers to the triad of hypercalcemia, metabolic alkalosis and renal insufficiency, resulting from the long-term ingestion of large amounts of calcium and absorbable alkali (mainly $\mathrm{CaCO}_{3}$ ) ${ }^{130}$ Although in individual cases and particularly in the presence of certain risk factors (impaired renal function, metabolic alkalosis) already $>1000 \mathrm{mg} / \mathrm{d}$ calcium may increase the risk of CAS, EFSA ${ }^{117}$ and $\mathrm{IoM}^{6}$ consider existing Upper Intake Levels (Table 1) as valid.

Table 4 Population-based and small intervention studies on calcium \pm vitamin $\mathrm{D}$ and urinary tract stones risk

\begin{tabular}{|c|c|c|c|c|c|}
\hline Study ${ }^{\S}$ & Participants $^{\$}$ & $\begin{array}{l}\text { Duration/ } \\
\text { Follow- } \\
\text { Up\& }\end{array}$ & $\begin{array}{l}\text { Diets/Intervention }^{+} \\
\text {(Mmol/D Dca/Sca/K/lu/D } \\
\text { Vitd) }\end{array}$ & Results & Litho-Genicity \\
\hline
\end{tabular}

A) Population-based, intervention and prospective cohort studies on total calcium intake and urinary tract stones risk

\begin{tabular}{|c|c|c|c|c|}
\hline $\begin{array}{l}\text { Different intervent. } \\
\text { Studie }^{s|2|}\end{array}$ & $5000 \mathrm{~s}$ & $3 \mathrm{mo}-4 \mathrm{y}$ & $8-45 \mathrm{dCa}+13-50 \mathrm{sCa}$ & rUTS \pm \\
\hline HPFS $^{122}$ & $45,619 \mathrm{~m}$ & $4 y$ & $\max (>26)$ vs. $\min (<15) \mathrm{dCa}$ & $\mathrm{rUTS} \downarrow t \mathrm{t} / \mathrm{dCa}$ \\
\hline HPS $^{123}$ & $45,619 \mathrm{~m}$ & $14 y$ & $\max (>30)$ vs. $\min (<13) \mathrm{dCa}$ & $\begin{array}{l}\mathrm{rUTS} \downarrow \uparrow / \pm \mathrm{dCa} / \mathrm{sCa} \\
(\mathrm{m}<60 \mathrm{y})\end{array}$ \\
\hline NHS I'24 & $91,731 \mathrm{w}$ & $12 y$ & $\max (34)$ vs. $\min (13) \mathrm{dCa}$ & $\mathrm{rUTS} \downarrow t \mathrm{t} / \mathrm{dCa}$ \\
\hline NHS III & $96,245 \mathrm{w}$ & $8 y$ & $\max (>28)$ vs. $\min (<16) \mathrm{dCa}$ & $\mathrm{rUTS} \downarrow \uparrow / \pm \mathrm{dCa} / \mathrm{sCa}$ \\
\hline
\end{tabular}

B) Population-based intervention studies on calcium plus vitamin d supplementation and urinary tract stones risk

$\begin{array}{lclll}\text { WHI85 } & 7 y & \text { Usual diet (incl. PsCa+PsVitD) } & \text { isrUTS/ (HzR I.I7) } \\ \text { WHI }{ }^{117} & 36,282 \mathrm{pmw} & 7 y & +25 \mathrm{CaCO}_{3} / 400 \text { Vit Dor placebo } & \text { isrUTS } \uparrow(2.1 \% \rightarrow 2.5 \% \text {; ns) }\end{array}$

C) Small intervention trials on calciumcitrate and urinary tract stones risk

\begin{tabular}{|c|c|c|c|c|}
\hline Harvey ${ }^{126}$ & $18 \mathrm{~s}$ & $\hookrightarrow \supset$ & 20 Ca Citr vs.placebo & $\begin{array}{l}\text { uCa }\left\{\text { uCitr } \uparrow ; u x_{\text {sat }} \downarrow \text {; }\right. \\
\text { uNP } \downarrow\end{array}$ \\
\hline Levine $^{127}$ & $14 \mathrm{sfw}$ & $6 \mathrm{mo}$ & $25 \mathrm{Ca}$ Citr (before-after) & $\begin{array}{l}\text { uCa } \uparrow ; \text { uCitr } \uparrow ; \\
\text { uCarbonateOx }\end{array}$ \\
\hline Sakhaee ${ }^{128}$ & $7 w$ & $3 \mathrm{mo}$ & 25 Ca Citr(before-after) & $\begin{array}{l}\mathrm{uCa} \uparrow ; \mathrm{uP} \downarrow ; \mathrm{uOx} \downarrow ; \mathrm{uCitr} \pm \\
\mathrm{uOx}_{\mathrm{sat}} \pm ; \mathrm{uBru}_{\mathrm{sat}} \pm ; \mathrm{uNP} \pm\end{array}$ \\
\hline
\end{tabular}
Sakhaee $^{129}$
$18 \mathrm{pmw}$
$4 \times 2$ wo; $\hookrightarrow \supset$
a) placebo; b) $2 \times 10 \mathrm{CaCitr}$
c) $2 \times 7 \mathrm{KCitr}$; d) $\mathrm{CaCitr}+\mathrm{KCitr}$
vs. placebo: uCa $\uparrow ; \mathrm{uCitr} \uparrow$; uCaOx $\downarrow$; uBru $\downarrow ; \mathrm{uUrAc} \downarrow$

$\pm$

Professional Study (follow-up); NHS, Nurses Health Study (I/II);WHI,Women's Health Initiative

\$S: Subjects; M, Men;W,Women; PM, Postmenopausal; SF, Stone-Forming \&MO, Month;Y,Year; С つ, cross over.

+T/D/SCa, Total/Dietary/Supplemental Ca; MaxVs Min: HighestVs Lowest Quintile; PS Ca/VitD, personal Ca/VitD suppl.; Ca/KCitr, Ca/Kcitrate

${ }^{*}$ r/isrUTS, Risc/Incidence of (self-reported) Urinary Tract Stones; $\downarrow \uparrow$, inverse association; \pm , no association/no effect/no increase; $\uparrow$, increase

uCa/uCitr/uP/uOx/uCaOx/uUrAc/uBru, Urinary Calcium/Citrate/Phosphate/Oxalic Acid/Calcium Oxalate/Uric Acid/Brushite(CaHPO ${ }_{4} 2 \mathrm{H}_{2} \mathrm{O}_{\text {); }}$

uOxsat/uBrusat/UNP, Urinary Oxalic Acid Saturation/Brushite Saturation/Nucleation Propensity; HZR, Hazard Ratio; : from...to...; ns: p>0.05 


\section{Calcium and cardiovascular diseases}

Epidemiological data, observational studies and randomized controlled trials indicate, that high calcium intake as well as a higher consumption of milk and milk products is inversely associated with cardiovascular risk factors (BMI, (abdominal) obesity, body fat, insulin resistance, LDL-cholesterol and blood pressure) ${ }^{132}$ and the risk of cardiovascular diseases (CVD), including high pressure and arterial stiffness, coronary heart disease (CHD), myocardial infarction and stroke. ${ }^{133-136}$ Even with these results, the contribution of calcium to the overall health effects of milk could not be estimated yet. ${ }^{137}$

Given these findings, it was surprising when a randomized clinical trial, in which the effect of $1000 \mathrm{mg} / \mathrm{d}$ TCC on the risk of myocardial infarction, stroke and sudden death has been investigated over 5years in 1471 postmenopausal New Zealand women, found an increased risk of CVD ( RR=2.12) with calcium supplements. ${ }^{138}$ Parts of the results were then confirmed by subsequent evaluation of studies that were not (or not primarily) designed for the investigation of CVD. ${ }^{139-142}$ As the cause of atherosclerotic disease, the acute rise in serum calcium was considered, that could be induced with supplemental but not with dietary calcium.

Other authors disagreed with these findings ${ }^{143-145}$ with regard to observational studies, meta-analyzes and RCTs, in which no higher cardiovascular risk through calcium with or without vitamin D supplementation has been demonstrated or in which an increased calcium intake was associated even with a reduced cardiovascular risk. $^{146-148}$ Indeed, only in six of 28 RCT and observational studies (published between 1992 and 2013), in which effects of calcium on CVD, CHD or stroke as a primary or secondary clinical end point had been examined, an increased risk can be observed, 18 show no effect and four even a lower risk (Table 5).

Table 5 RCT and observational studies (published between 1992 and 20/3), showing no, positive or negative effects of dietary and/or supplemental calcium \pm vitamin $\mathrm{D}$ on CVD, CHD or stroke risk. ${ }^{.51,152}$

\begin{tabular}{|c|c|c|c|c|c|c|}
\hline Study end point & Form of calcium administration & Study design & $\mathbf{N}$ & $\begin{array}{l}\text { Increasd } \\
\text { risk }\end{array}$ & No effect & Lower risk \\
\hline \multirow[t]{2}{*}{ CVD } & Supplements \pm Vit $D$ & RCTs & 6 & & 5 & I (ns) \\
\hline & Supplements+intake & Observational & 3 & 3 & & \\
\hline \multirow[t]{3}{*}{ CHD } & Supplements & RCTs & 4 & 2 & 2 & \\
\hline & Intake & Observational & 6 & & 5 & I \\
\hline & Supplements & $\mathrm{RCT}$ & 1 & I & & \\
\hline \multicolumn{7}{|l|}{ Stroke } \\
\hline & Intake & Observational & 8 & & 6 & 2 \\
\hline Total & & & 28 & 6 & 18 & 4 (Ix ns) \\
\hline
\end{tabular}

And in a recent meta-analysis of 18 randomized controlled studies (with a total of 63,563 participating elderly women) on the effect of calcium on CHD risk (myocardial infarction, angina pectoris, acute coronary syndrome and chronic CHD) and all-cause mortality, the investigators came to the conclusion, that "current evidence does not support the hypothesis that calcium supplementation with or without vitamin D increases coronary heart disease or all-cause mortality risk". ${ }^{49}$

In other studies, the increase in serum calcium induced by TCC supplements did not cause a particular high CVD risk, but resulted in changes of vascular parameters that in the long term could reduce that risk. ${ }^{150,151}$

These conflicting study results may be explained, to a certain extent, with methodological weaknesses and also with the slowness of many calcium-dependent processes. For example, where as in the "Women's Health Initiative" (WHI; see 5.1.) the risk of cardiovascular events through consumption of calcium supplements was not or only very slightly increased during intervention and in the first years thereafter, evaluation of the overall study period even shows a rise of the cumulative hazard in the control group 13years after start of the study $^{99}$ (Figure 6).

All in all, an increased CHD/CVD risk through higher calcium consumption within consumption recommendations cannot be derived from the available data. Correspondingly, the EFSA Panel on Dietetic Products, Nutrition and Allergies (NDA) considered in 2012, that long-term calcium intakes from diet and supplements up to $2500-3000 \mathrm{mg} /$ day are not associated with an increased risk of cardiovascular disease in adults. ${ }^{117}$

\section{Mortality}

In most studies and meta-analyses, an increased calcium intake (be it from food or from supplements) was not associated with increased 
mortality due to vascular diseases ${ }^{153-156}$ Additionally (total) mortality was even decreased such as in the Iowa Women's Health Study ${ }^{157}$ and in the WHI study, ${ }^{158}$ an increase in mortality hazard ratio with age was more pronounced in the placebo group (Figure 7). In one study, ${ }^{159}$ mortality showed a U-shaped curve, whereby an intake of dietary plus supplemental calcium between 600 and $1400 \mathrm{mg} / \mathrm{d}$ was associated with the lowest mortality.

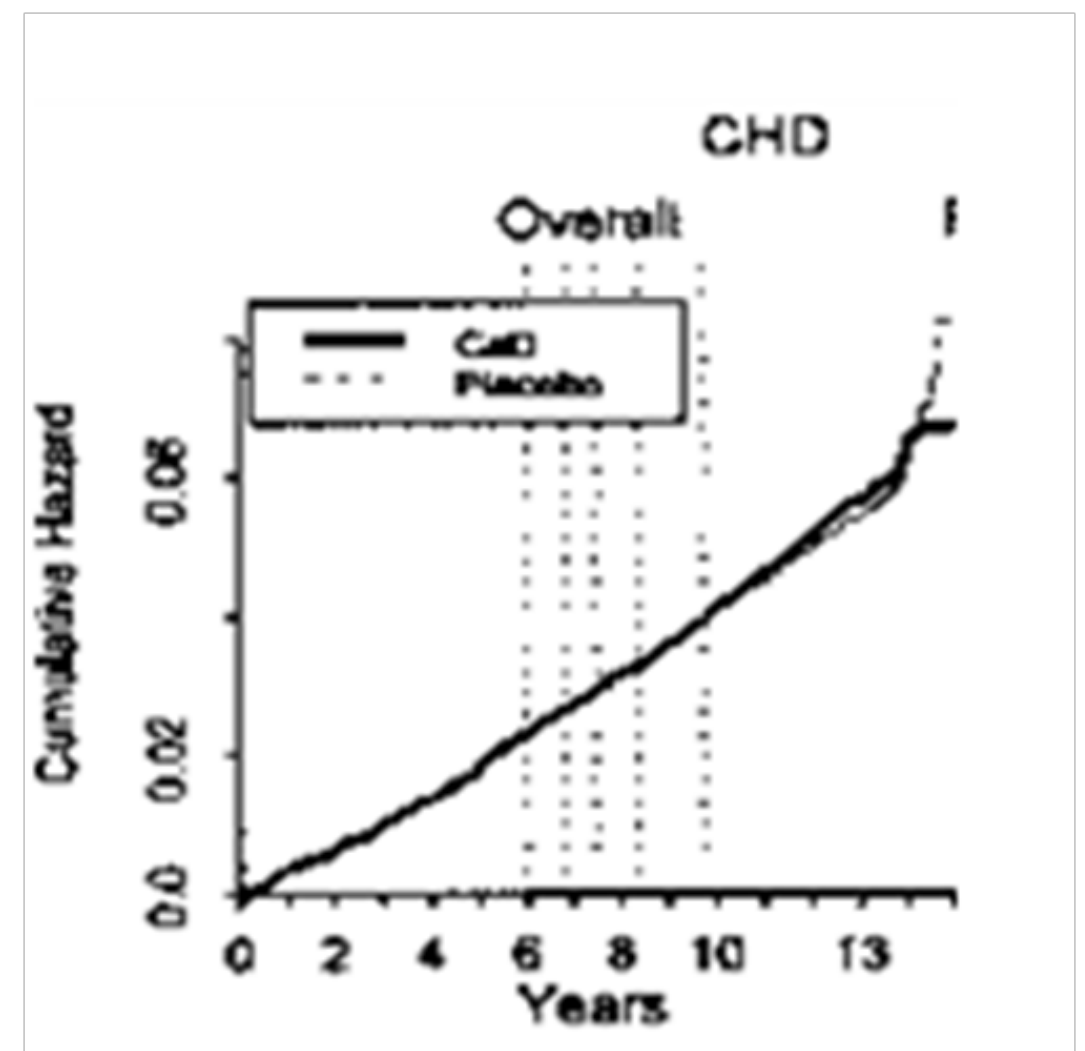

Figure 6 Effect of daily supplementation with $1000 \mathrm{mg}$ calcium plus $400 \mathrm{IU}$ vitamin Din the Women's Health Iniative (WHI) CaD supplementation trial on cumulative CHD risk during intervention (7years) and 7years follow-up. ${ }^{99}$

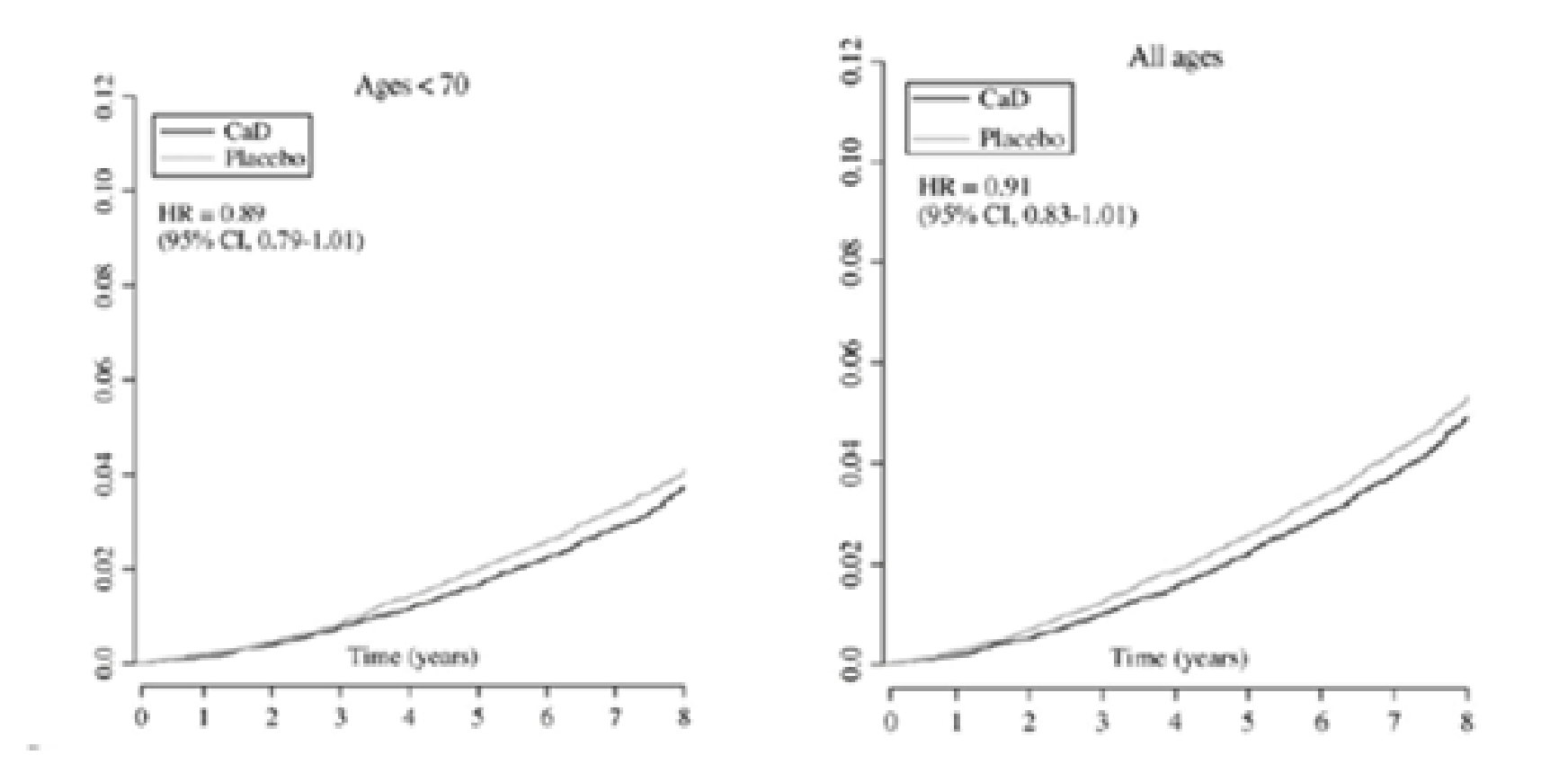

Figure 7 Effect of daily supplementation with $1000 \mathrm{mg}$ calcium plus $400 \mathrm{IU}$ vitamin D in the Women's Health Iniative (WHI) CaD supplementation trial on cumulative hazard ratios of all-cause mortality in women of all ages and $<70 y .99,158$ 


\section{Gastrointestinal Complaints}

Calcium carbonate is reported to cause gastrointestinal complaints (upper gastrointestinal gas, bloating or constipation) in sensitive persons, ${ }^{160}$ which for chemical reasons do not occur with TCC [Section 4.5].

\section{Effects on mineral absorption}

Dietary and supplemental calcium at intake levels of current recommendations have been shown to reduce iron and zinc absorption in short term trials. This effect, however, vanished after prolonged continuation of the experiment as well as has not been observed in long-term observational and intervention studies. ${ }^{122,161}$ TCC is thought to have a smaller or only a marginal negative effect due to the enhancement of mineral and particularly iron absorption by citric acid. $^{162}$

\section{Calcium and prostate cancer}

Several prospective studies and meta-analyses suggest a significantly increased risk of prostate cancer due to increased intake of dietary or supplemental calcium ( $>1500 \mathrm{mg} / \mathrm{d}),{ }^{163,164}$ whereas other large prospective studies ${ }^{165}$ and meta-analyses ${ }^{166}$ found no association between dietary and supplemental calcium and prostate cancer or even a protective effect. ${ }^{167}$ However, it is not clear whether the effect of calcium on prostate carcinogenesis results from the calcium-mediated decrease in 1,25-dihydroxy-vitamin $\mathrm{D}_{3}$, which is thought to have a protective effect against prostate cancer. All in all, available data does not allow for recommendations to decrease or increase calcium intake for cancer prevention. ${ }^{168,169}$

\section{Summery and conclusions}

High calcium intake seems to have a small positive effect on bone mineral content (BMC) and bone mineral density (BMD) in children and postmenopausal women. There is no consistent evidence on the effects of calcium on bone health in premenopausal women or men. Also, the evidence that calcium supplementation reduces fracture incidence is scarce and inconsistent. ${ }^{170}$

On the other hand, the available data do not provide evidence for an increased risk of kidney stones, cardiovascular diseases and stroke due to higher calcium consumption within intake recommendations.

Therefore, it is not recommended by the respective authorities to change existing intake recommendations or to reduce calcium consumption. These recommendations were not designed to reduce the risk of fractures and osteoporosis and other adverse health effects, but to cover the physiological calcium requirements of certain population groups. This is primarily because of an insufficient quality and contradictory results of the respective clinical studies and metaanalyses.

Therefore the usually quite high intake recommendations for calcium in industrialized "Western" countries is a result from increased calcium requirements in a "Western style" diet, which, inter alias, are due to its high content of (animal) protein. An increased protein intake is not a risk per se, and may even promote bone growth and bone health, when at the same time adequate calcium intake is guaranteed.

A particular risk for inadequate calcium supply exists during skeletal growth and age-related reduced nutrient and therefore calcium intake. At risk groups include: children and adolescents between 10 and 19years; women over 19 (in the US) or women aged between 19 and 25 and over 65years (in the EU); very old, and frequently hospitalized and malnourished people; and lean and physically active (ballet, gymnastic) girls and women.

It is recommended by the respective nutrition societies to meet calcium intake needs by eating calcium-rich foods (in western countries mainly milk and milk products), because calcium administration within a meal is thought to delay calcium absorption and thereby to reduce peak concentrations in serum calcium and the risk of vascular calcification and other side effects. With a "Western style" diet and a calcium absorption rate of $25-30 \%$, daily consumption of 4 servings of milk or dairy products (e.g. 250g milk and yogurt or 1-2 slices of hard cheese per serving) or other calcium-rich foods would be necessary to meet recommended calcium requirements of $1000-1200 \mathrm{mg} / \mathrm{d}$ for adolescents and adults.

However, it is recognized that many people are not able or willing to meet these requirements through foods naturally containing calcium. For these people, calcium-fortified food or a wide range of calcium supplements (with or without added vitamin D) is available. $\mathrm{CaCO}_{3}$ and TCC are among the compounds most frequently used for this purpose.

TCC has an intermediate calcium content $(21 \%)$ and, because of the lack of potential side effects and the neutral taste, a good compliance. Solubility of TCC is $\mathrm{pH}$ dependent; it increases with decreasing $\mathrm{pH}$, and exceeds that of $\mathrm{CaCO}_{3}$ above $\mathrm{pH}$ 6.6. This means that TCC is more soluble than $\mathrm{CaCO}_{3}$ from the middle of the jejunum to the colon The amount of absorbable free $\mathrm{Ca}^{2+}$-ions in the chyme depends on the solubility of the respective calcium salt, the presence of complexing agents and an adequate production of gastric juice, by which also less soluble calcium compounds like $\mathrm{CaCO}_{3}$ or TCC are converted into easily soluble $\mathrm{CaCl}_{2}$ or better said into $\mathrm{Ca}^{2+}$ - and $\mathrm{Cl}^{-}$ions.

Due to the irreversibility of Trans- and par cellular calcium absorption, poorly soluble calcium compounds and calcium complexes may also provide sufficient calcium ions for absorption. Therefore absorption and bioavailability of TCC compared to $\mathrm{CaCO}_{3}$ cannot be derived by theoretical considerations but has been examined in a number of randomized, controlled human trials and by a metaanalysis, demonstrating a significantly higher bioavailability (about $+24 \%$ ) of TCC compared to $\mathrm{CaCO}_{3}$.

The association between acute effects of high calcium absorption on serum calcium concentration and long term effects on BMD, bone structure and fracture incidence is generally poor. Nevertheless, a higher intake of TCC has led to increased bone mineral density (BMD) and reduced bone loss and serum PTH in a number of randomized controlled studies in elderly pre- and postmenopausal women. One of the reasons for this may be the good bioavailability and the sufficient calcium content of TCC.

Other, often mentioned advantages of TCC compared to $\mathrm{CaCO}_{3}$ are the following:

a. For optimum absorption and bioavailability, TCC does not require gastric acid. Therefore, and particularly when not administered as part of a meal, TCC may be the better choice in achlorhydric subjects, in elderly people with impaired gastric acid production or in patients using gastric acid inhibitors.

b. Citrate complexation of calcium and an enhanced citrate excretion, which augments the inhibitory activity against calcium oxalate crystallization, may minimize the risk of urinary calcium oxalate stones. 
c. Other side effects, which are attributed rather to $\mathrm{CaCO}_{3}$ than to TCC, are: $\mathrm{CaCO}_{3}$ gallstones, the calcium-alkali syndrome (CAS), discomfort associated with the release of gaseous $\mathrm{CO}_{2}$ in the stomach, or rebound hyperacidity, i.e. the stomach overcompensates for the high dose of alkaline calcium carbonate by the secretion of more acid.

d. These beneficial properties of calcium supplements and particularly TCC may be optimized through suitable dosage forms, a smaller particle size and measures to achieve more even calcium absorption.

\section{Conflicts of interest}

The authors declare that they have no competing interests. The Coauthor, Gerhard Gerstner, is Business Development Director Health \& Nutrition at Jungbunzlauer Ladenburg GmbH, Germany, which, among other products manufacture organic calcium salts, including TCC

\section{Funding source}

Publication was financially supported by Jungbunzlauer Ladenburg GmbH, Germany.

\section{References}

1. Robertson WG, Marshall RW. Calcium measurements in serum and plasma-Total and ionized. CRC Crit Rev Clin Lab Sci. 1979;11(3):271-304.

2. Committee to Review Dietary Reference Intakes for Vitamin D and calcium, Food and Nutrition Board. Institute of Medicine. Dietary Reference Intakes for Calcium and Vitamin D. Washington DC: National Academy Press; 2010

3. Campbell AK.Calcium as an intracellular regulator. Proc Nutr Soc. 1990;49(1):51-56.

4. Bootman MD, Collins TJ, Peppiatt CM, et al. Calciumsignalling-An overview. Semin Cell Dev Biol. 2001;12(1):3-10.

5. Food and Agricultural Organization of the United Nations: World Health Organization. Human vitamin and mineral requirements. Report of a joint FAO: WHO expert consultation, Bangkok, Thailand. Rome: Food and Agricultural Organization of the United Nations. 2001.

6. IOM Institute of Medicine. Dietary Reference Intakes for Calcium and Vitamin D. Washington (DC): National Academies Press; 2011:1133.

7. European Food Safety Authority (EFSA) Panel on Dietetic Products, Nutrition and Allergies (NDA). Dietary Reference Values for calcium. EFSA Journal. 2015;13:4101.

8. D-A-CH (Deutschland-Austria-Confoederatio Helvetica). Referenzwerte für die Nährstoffzufuhr. 2. Auflage, 1. Ausgabe. Deutsche Gesellschaft für Ernährung, Österreichische Gesellschaft für Ernährung, Schweizerische Gesellschaft für Ernährung, 2015. 215p.

9. New reference values for calcium. Ann Nutr Metab. 2013;63(3):186-192

10. Ross AC, Manson JE, Abrams SA, et al. The 2011 report on dietary reference intakes for calcium and vitamin $\mathrm{D}$ from the Institute of Medicine: what clinicians need to know. J Clin Endocrinol Metab. 2011;96(1):53-58.

11. Cohn JN. Introduction to Surrogate Markers. Circulation. 2004;109(25 Suppl 1):IV20-1.

12. Teegarden D, Proulx WR, Martin BR, et al. Peak bone mass in young women. J Bone Miner Res. 1995;10(5):711-715.
13. Darelid A, Ohlsson C, Nilsson M, et al. Catch up in bone acquisition in young adult men with late normal puberty. $J$ Bone Miner Res. 2012;27(10):2198-2207.

14. Weaver CM. Age related calcium requirements due to changes in absorption and utilization. J Nutr. 1994;124(8 Suppl):1418S-1425S.

15. Wastney ME, Ng J, Smith D, et al. Differences in calcium kinetics between adolescent girls and young women. American Journal of Physiology. 1996;271(1):R208-R216.

16. Abrams SA, Copeland KC, Gunn SK, et al. Calcium absorption and kinetics are similar in 7 and 8year-old Mexican-American and Caucasian girls despite hormonal differences. J Nutr. 1999;129(3):666-671.

17. Lynch MF, Griffin IJ, Hawthorne KM, et al. Calcium balance in 1-4-y-old children. Am J Clin Nutr. 2007;85(5):750-754.

18. Vatanparast H, Bailey DA, Baxter-Jones AD, et al. Calcium requirements for bone growth in canadian boys and girls during adolescence. $\mathrm{Br} J$ Nutr. 2010;103(4):575-580.

19. Hunt CD, Johnson LK. Calcium requirements: new estimations for men and women by cross-sectional statistical analyses of calcium balance data from metabolic studies. Am J Clin Nutr. 2007;86(4):1054-1063.

20. Hicks PD, Hawthorne KM, Berseth CL, et al. Total calcium absorption is similar from infant formulas with and without prebiotics and exceeds that in human milk-fed infants. BMC Pediatr. 2012;12:118.

21. Heseker H, Oepping A, Vohmann C Verzehrsstudiezur Ermittlung der Lebensmittelauf- nahme von Säuglingen und Kleinkindernfür die Abschätzungeinesakuten Toxizitätsrisikosdurch Rückstände von Pflanzenschutzmitteln (VELS). Forschungsbericht der Universität Paderborn im Auftrag des Bundesministeriumsfür Verbraucherschutz, Ernährung und Landwirtschaft, Bonn. 2003.

22. Mensink GBM, HesekerH, StahlA, et al. Die aktuelle Nährstoffversorgung von Kindern und Jugendlichen in Deutschland. Ergebnisseaus EsKiMo. Ernährungsumschau. 2007;11:636-646.

23. Max Rubner-Institut Edt Nationale Verzehrsstudie II. Karlsruhe, Germany; 2008.

24. Gibbs JC, Williams NI, De Souza MJ. Prevalence of individual and combined components of the female athlete triad. Med Sci Sports Exerc. 2013;45(5):985-996.

25. Nattiv A, Loucks AB, Manore MM, et al. American College of Sports Medicine. American College of Sports Medicine position stand: the female athlete triad. Med Sci Sports Exerc. 2007;39(10):1867-1882.

26. Huang KS. How economic factors influence the nutrient content of diets. Food and Rural Economics Division. Economics Research Service, Department of Agriculture Technical Bulletin, USA; 1997. 20p.

27. Larsson CL, Johansson GK. Dietary intake and nutritional status of young vegans and omnivores in Sweden. Am J Clin Nutr. 2002;76(1):100-106.

28. New SA. Do vegetarians have a normal bone mass? Osteoporos Int. 2004;15(9):679-688

29. Linkswiler HM, Zemel MB, Hegsted M, et al. Protein-induced hypercalciuria. Fed Proc. 1981;40(9):2429-2433.

30. Margen S, Chu JY, Kaufmann NA, et al. Studies in calcium metabolism 1. The calciurietic effect of dietary protein. Am J Clin Nut. $1974 ; 27: 584-589$

31. Kerstetter JE, O'Brien KO, Insogna KL. Low protein intake: the impact on calcium and bone homeostasis in humans. $J$ Nutr. 2003;133(3):855S-861S.

32. Munger RG, Cerhan JR, Chiu BC. Prospective study of dietary protein intake and risk of hip fracture in postmenopausal women. Am J Clin Nutr. 1999;69(1):147-152. 
33. Wengreen HJ, Munger RG, West NA, et al. Dietary protein intake and risk of osteoporotic hip fracture in elderly residents of Utah. $J$ Bone Miner Res. 2004;19(4):537-545.

34. Hannan MT, Tucker KL, Dawson-Hughes B, et al. Effect of dietary protein on bone loss in elderly men and women: the Framingham Osteoporosis Study. J Bone Miner Res. 2000;15(12):2504-2512.

35. Mangano KM, Sahni S, Kerstetter JE. Dietary protein is beneficial to bonehealth under conditions of adequate calcium intake: an update on clinical research. Curr Opin Clin Nutr Metab Care. 2014;17(1):69-74.

36. Fenton TR, Tough SC, Lyon AW, et al. Causal assessment of dietary acid load and bone disease: a systematic review \& meta-analysis applying Hill's epidemiologic criteria for causality. Nutr J. 2011;10:41-64.

37. Bonjour JP. Calcium and phosphate: a duet of ions playing for bone health. J Am Coll Nutr. 2011;(5 Suppl 1):438S-448S.

38. Matkovic V, Ilich JZ, Andon MB, et al. Urinary calcium, sodium, and bone mass of young females. Am J Clin Nutr. 1995;62(2):417-425.

39. Devine A, Criddle RA, Dick IM, et al. A longitudinal study of the effect of sodium and calcium intakes on regional bone density in postmenopausal women. Am J Clin Nutr. 1995;62(4):740-745.

40. O Brien KO, Abrams SA, Stuff JE, et al. Variables related to urinary calcium excretion in young girls. $J$ Pediatr Gastroenterol Nutr. 1996;23(1):8-12.

41. Heaney RP, Weaver CM. Oxalate: Effect on calcium absorbability. Am J Clin Nutr. 1989;50(4):830-832.

42. Weaver CM, Heaney RP, Martin BR, et al. Human calcium absorption from whole-wheat products. J Nutr. 1991;121(11):1769-1775.

43. McCance RA, Widdowson EM. Mineral metabolism of healthy adults on white and brown bread dietaries. J Physiol. 1942;101(1):44-85.

44. Massey LK, Whiting SJ. Caffeine, urinary calcium, calcium metabolism and bone. J Nutr. 1993;123(9):1611-1614.

45. Heaney RP, Weaver CM, Fitzsimmons ML. Soybean phytate content effect on calcium absorption. Am J Clin Nutr. 1991;53(3):745-747.

46. Heaney RP, Weaver CM. Effect of psyllium on absorption of co-ingested calcium. J Am Geriatr Soc. 1995;43(3):261-263.

47. Tsugawa N, Okano T, Higashino R, et al. Bioavailability of calcium from calcium carbonate, DL-calcium lactate, L-calcium lactate and powdered oyster shell calcium in vitamin D-deficient or -replete rats. Biol Pharm Bull. 1995;18(5):677-682.

48. Huang S, Chen JC, Hsu CW, et al. Effects of nanocalciumcarbonate and nanocalciumcitrate on toxicity in ICR mice and on bone mineral density in an ovariectomized mice model. Nanotechnology. 2009;20(37):375102.

49. Wang H, Bua P, Capodice J. A comparative study of calcium absorption following single serving administration of calcium carbonate powder versus calcium citrate tablets in healthy premenopausal women. Food Nutr Res. 2014;22:58.

50. Regulation (EC) No 1925/2006 of the European Parliament and of the Council of 20 December 2006 on the addition of vitamins and minerals and of certain other substances to food. EUR-Lex.

51. Tang BM, Eslick GD, Nowson C, et al. Use of calcium or calcium in combination with vitamin D supplementation to prevent fractures and bone loss in people aged 50years and older: a meta-analysis. Lancet. 2007;370(9588):657-666.

52. Fleet JC, Schoch RD. Molecular mechanisms for regulation of intestinal calcium absorption by vitamin D and other factors. Crit Rev Clin Lab Sci. 2010;47(4):181-195.

53. Hoenderop JG, Nilius B, Bindels RJ. Calcium absorption across epithelia. Physiol Rev. 2005;85(1):373-422.
54. Bronner F, Pansu D. Nutritional aspects of calcium absorption. J Nutr. 1999;129(1):9-12.

55. Wasserman RH. Vitamin D and the dual processes of intestinal calcium absorption. J Nutr. 2004;134(11):3137-3139.

56. Bronner F, Slepchenko B, Wood RJ, et al. The role of passive transport in calcium absorption. J Nutr. 2003;133(5):1426.

57. McCormick CC. Passive diffusion does not play a major role in the absorption of dietary calcium in normal adults. J Nutr. 2002;132(11):34283430 .

58. Heaney RP, Recker RR, Stegman MR, et al. Calcium absorption in women: relationships to calcium intake, estrogen status, and age. J Bone Miner Res. 1989;4(4):469-475.

59. Hanzlik RP, Fowler SC, Fisher DH. Relative bioavailability of calcium from calcium format, calcium citrate, and calcium carbonate. $J$ Pharmacol Exp Ther. 2005;313(3):1217-1222.

60. Goss SL, Lemons KA, Kerstetter JE, et al. Determination of calcium salt solubility with changes in $\mathrm{pH}$ and PCO2, Simulating varying gastrointestinal environments. $J$ Pharm Pharmacol. 2007;59(11):1485-1492.

61. Van der Velde RY, Brouwers JR, Geusens PP, et al. Calcium and vitamin D supplementation: state of the art for daily practice. Food Nutr Res. 2014;7:58

62. Favus MJ, Pak C. Evidence for absorption of ionic calcium and soluble calcium complexes by the duodenum and cecum in the rat. Am J Ther 2001;8(6):425-431.

63. Heaney RP, Recker RR, Weaver CM. Absorbability of calcium sources: the limited role of solubility. Calcif Tissue Int. 1990;46(5):300-304.

64. Sakhaee K, Bhuket T, Adams-Huet B, et al. Meta-analysis of calcium bioavailability: a comparison of calcium citrate with calcium carbonate. Am J Ther. 1999;6(6):313-321.

65. Bo-Linn GW, Davis GR, Buddrus DJ, et al. An evaluation of the importance of gastric acid secretion in the absorption of dietary calcium. J Clin Invest. 1984;73(3):640-647.

66. Nicar MJ, Pak CY. Calcium bioavailability from calcium carbonate and calcium citrate. J Clin Endocrinol Metab. 1985;61(2):391-393.

67. Recker RR. Calcium absorption and achlorhydria. $N$ Engl $\mathrm{J}$ Med. 1985;313(2):70-73.

68. Reid IR, Hannan SF, Schoolar BA, et al. The acute biochemical effects of four proprietary calcium preparations. Aust NZ J Med. 1986;16:193-197.

69. Harvey JA, Zobitz MM, Pak CY. Dose dependency of calcium absorption: a comparison of calcium carbonate and calcium citrate. $J$ Bone Miner Res. 1988;3(3):253-258.

70. Sheikh MS, Santa Ana CA, Nicar MJ, et al. Gastrointestinal absorption of calcium from milk and calcium salts. $N$ Engl $\mathrm{J} \mathrm{Med}$. 1987;317(9):532-536

71. Harvey JA, Kenny P, Poindexter J, et al. Superior calcium absorption from calcium citrate than calcium carbonate using external forearm counting. J Am Coll Nutr. 1990;9(6):583-587.

72. Harvey JA, Zobitz MM, Pak CY. Dose dependency of calcium absorption: a comparison of calcium carbonate and calcium citrate. $J$ Bone Miner Res. 1988;3(3):253-258.

73. Heaney RP, Dowell MS, Barger-Lux MJ. Absorption of calcium as the carbonate and citrate salts, with some observations on method. Osteoporos Int. 1999;9(1):19-23.

74. Micheletti MC, Zartarian M. Comparison of calcium retention measured using a radionuclide method after administration of $1000 \mathrm{mg}$ elemental calcium in two different galenic forms, in one or two doses. Rev Rhum Engl Ed. 1996;63(1):51-55. 
75. Heller HJ, Stewart A, Haynes S, et al. Pharmacokinetics of calcium absorption from two commercial calcium supplements. $J$ Clin Pharmacol. 1999;39(11):1151-1154.

76. Heller HJ, Greer LG, Haynes S, et al. Pharmacokinetic and pharmacodynamic comparison of two calcium supplements in postmenopausal women. J Clin Pharmacol. 2000;40(11):1237-1244.

77. Heaney RP, Dowell MS, Bierman J, et al. Absorbability and cost effectiveness in calcium supplementation. J Am Coll Nutr. 2001;20(3):239-246.

78. Kenny AM, Prestwood KM, Biskup B, et al. Comparison of the effects of calcium loading with calcium citrate or calcium carbonate on bone turnover in postmenopausal women. Osteoporos Int 2004;15(4):290-294.

79. Thomas SD, Need AG, Tucker G, et al. Suppression of parathyroid hormone and bone resorption by calcium carbonate and calcium citrate in post- menopausal women. Calcif Tissue Int. 2008;83(2):81-84.

80. Karp HJ, Ketola ME, Lamberg-Allardt CJ. Acute effects of calcium carbonate, calcium citrate and potassium citrate on markers of calcium an bone metabolism in young women. Br J Nutr. 2009;102(9):1341-1347.

81. Heller HJ, Poindexter JR, Adams-Huet B. Effect of estrogen treatment and vitamin D status on differing bioavailabilities of calcium carbonate and calcium citrate. J Clin Pharmacol. 2002;42(11):1251-1256.

82. Tondapu P, Provost D, Adams-Huet B, et al. Comparison of the absorption of calcium carbonate and calcium citrate after Roux-en-Y gastric bypass. Obes Surg. 2009;19(9):1256-1261.

83. Hade JE, Spiro HM. Calcium and acid rebound: a reappraisal. J Clin Gastroenterol. 1992;15(1):37-44.

84. Stringer MD, Soloway RD, Taylor DR, et al. Calciumcarbonate gallstones in children. J Pediatr Surg. 2007;42(10):1677-1682.

85. Bischoff-Ferrari HA, Dawson-Hughes B, Baron JA, et al. Calcium intake and hip fracture risk in men and women: a meta-analysis of prospective cohort studies and randomized controlled trials. Am J Clin Nutr. 2007;86(6):1780-1790.

86. Jackson RD, LaCroix AZ, Gass M, et al. Calcium plus vitamin D supplementation and the risk of fractures. $N$ Engl J Med. 2006;354(7):669-683

87. Zhou W, Langsetmo L, Berger $\mathrm{C}$, et al. Longitudinal changes in calcium and vitamin $\mathrm{D}$ intakes and relationship to bone mineral density in a prospective population-based study: the Canadian Multicentre Osteoporosis Study (CaMos). J Musculoskelet Neuronal Interact. 2013;13(4):470-479.

88. DIPART (Vitamin D Individual Patient Analysis of Randomized Trials) Group. Patient level pooled analysis of 68500 patients from seven major vitamin D fracture trials in US and Europe. BMJ. 2010;340:5463.

89. Moyer VA. Vitamin D and calcium supplementation to prevent fractures in adults: U.S. Preventive Services Task Force recommendation statement. Ann Intern Med. 2013;158(9):691-696.

90. Grant AM, Avenell A, Campbell MK, et al. Oral vitamin D3 and calcium for secondary prevention of low-trauma fractures in elderly people (randomised evaluation of calcium or vitamin $\mathrm{D}$, record): a randomised placebo-controlled trial. Lancet. 2005;365(9471):1621-1628.

91. Winzenberg T, Shaw K, Fryer J, et al. Effects of calcium supplementation on bone density in healthy children: meta-analysis of randomised controlled trials. BMJ online. 2006;333(7572):775.

92. Ruml LA, Sakhaee K, Peterson R, et al. The effect of calcium citrate on bone density in the early and mid-postmenopausal period: a randomized, placebo-controlled study. Am J Ther. 1999;6(6):303-311.
93. McKane WR, Khosla S, Egan KS, et al. Role of calcium intake in modulating age-related increases in parathyroid function and bone resorption. J Clin Endocrinol Metab. 1996;81(5):1699-1703.

94. Prestwood KM, Pannullo AM, Kenny AM, et al. The effect of a short course of calcium and vitamin D on bone turnover in older women. Osteoporos Int. 1996;6(4):314-319.

95. Riggs BL, O'Fallon WM, Muhs J, et al. Long-term effects of calcium supplementation on serum PTH, bone turnover, and bone loss in elderly women. J Bone Min Res. 1996;13(12):168-174.

96. Rosen CJ. Clinical practice. Vitamin D insufficiency. $N$ Engl J Med. 2011;364(3):248-254

97. Chung M, Lee J, Terasawa T, et al. Vitamin D with or without calcium supplementation for prevention of cancer and fractures: an updated meta-analysis for the U.S. preventive services task force. Ann Intern Med. 2011;155(12):827-838.

98. Avenell A, Gillespie WJ, Gillespie LD, et al. Vitamin D and vitamin D analogues for preventing fractures associated with involutional and post-menopausal osteoporosis. Cochrane Database Syst Rev 2005;3:CD000227.

99. Cauley JA, Chlebowski RT, Wactawski-Wende J, et al. Calcium plus vitamin Dsupplementation and health outcomes five years after active intervention ended:the Women's Health Initiative. J Womens Health (Larchmt). 2013;22(11):915-929.

100. Prentice RL, Pettinger MB, Jackson RD, et al. Health risks and benefits from calcium and vitamin d supplementation: women's health initiative clinical trial and cohort study. Osteoporos Int. 2013;24(2):567-580.

101. Major GC, Chaput JP, Ledoux M, H, et al. Recent developments in calcium-related obesity research. Obes Rev. 2008;9(5):428-445.

102.Zemel MB, Thompson W, Milstead A, et al. Calcium and dairy acceleration of weight and fat loss during energy restriction in obese adults. Obes Res. 2004;12(4):582-890.

103. Scholz-Ahrens K E, Schrezenmeir J. Milk minerals and the metabolic syndrome. International dairy journal. 2006;16(11):1399-1407.

104. Pittas AG, Lau J, Hu FB, et al. The role of vitamin D and calcium in type 2 diabetes. A systematic review and meta-analysis. $J$ Clin Endocrinol Metab. 2007;92(6):2017-2029

105. Pittas AG, Dawson-Hughes B, Li T, et al. Vitamin D and calcium intake in relation to type 2 diabetes in women. Diabetes Care. 2006;29(3):650-656

106. Choi HK, Willett WC, Stampfer MJ, et al. Dairy consumption and risk of type 2 diabetes mellitus in men. Arch Intern Med. 2005;165(9):997-1003.

107. van Mierlo LA, Arends LR, Streppel MT, et al. Blood pressure response to calcium supplementation: a meta-analysis of randomized controlled trials. J Hum Hypertens. 2006;20(8):571-580.

108. Zemel MB, Sun X, Sobhani T, et al. Effects of dairy compared with soy on oxidative and inflammatory stress in overweight and obese subjects. Am J Clin Nutr. 2010;91(1):16-22.

109. van Meijl LEC, Mensink RP. Effects of low-fat dairy consumption on markers of low-grade systemic inflammation and endothelial function in overweight and obese subjects: an intervention study. $\mathrm{Br} J \mathrm{Nutr}$. 2010;104(10):1523-1527.

110. Choi EY, Kim HJ, Han JS. Anti-inflammatory effects of calcium citrate in RAW 264.7cells via suppression of NF-kB activation. Environ Toxicol Pharmacol. 2015;39(1):27-34.

111. Vaskonen T (2003) Dietary minerals and modification of cardiovascular risk factors. J Nutr Biochem. 2003;14(9):492-506. 
112. Ping-Delfos WC, Soares MJ, Cummings NK. Acute suppression of spontaneous food intake following dairy calcium and vitamin D. Asia Pacific J Clinical Nutr. 2004;13:82.

113. Zemel MB. Regulation of adiposity and obesity risk by dietary calcium: mechanisms and implications. J Am Coll Nutr. 2002;21(2):146S-151S.

114. Zemel MB, Shi H, Greer B, et al. Regulation of adiposity by dietary calcium. FASEB J. 2000;14(9):1132-1138.

115. Zemel MB. Calcium modulation of hypertension and obesity: Mechanisms and implications. J Am Coll Nutr. 2001;20(suppl):428S-435S.

116. Gault MH, Chafe L. Relationship of frequency, age, sex, stone weight and composition in 15,624 stones: comparison of results for 1980 to 1983 and 1995 to 1998. J Urol. 2000;164(2):302-307.

117. Panel on Dietetic Products, Nutrition and Allergies (NDA). Scientific Opinion on the Tolerable Upper Intake Level of calcium. EFSA Journal. 2012;10(7):2814.

118. Wallace RB, Wactawski-Wende J, O'Sullivan MJ, et al. Urinary tract stone occurrence in the Women's Health Initiative (WHI) randomized clinical trial of calcium and vitamin D supplements. Am J Clin Nutr. 2011;94(1):270-277.

119. Caudarella R, Vescini F. Urinary citrate and renal stone disease: the preventive role of alkali citrate treatment. Arch Ital Urol Androl. 2009;81(3):182-187.

120. Sorensen MD. Calcium intake and urinary stone disease. Translational Andrology and Urology (TAU). 2014;3(3):235-240.

121.Pak CY, Fuller C. Idiopathic hypocitraturic calcium-oxalate nephrolithiasis successfully treated with potassium citrate. Ann Intern Med. 1986;104(1):33-37.

122. Opinion on the Tolerable Upper Intake Level of calcium. SCF/CS/NUT/ UPPLEV/64 Final SCF (Scientific Committee on Food), USA; 2003. $39 \mathrm{p}$.

123. Curhan GC, Willett WC, Rimm EB, et al. A prospective study of dietary calcium and other nutrients and the risk of symptomatic kidney stones. New England Journal of Medicine. 1993;328:833-838.

124. Taylor EN, Stampfer MJ, Curhan GC. Dietary factors and the risk of incident kidney stones in men: new insights after 14 years of follow-up. Journal of the American Society of Nephrology. 2004;15(12):3225-3232.

125. Curhan GC, Willett WC, Speizer FE, et al. Comparison of dietary calcium with supplemental calcium and other nutrients as factors affecting the risk for kidney stones in women. Ann Intern Med. 1997;126(7):497-504.

126. Curhan GC, Willett WC, Knight EL, et al. Dietary factors and the risk of incident kidney stones in younger women: Nurses' Health Study II. Arch Intern Med. 2004;164(4):885-891.

127. Harvey JA, Zobitz MM, Pak CY. Calcium citrate: reduced propensity for the crystallization of calcium oxalate in urine resulting from induced hypercalciuria of calcium supplementation. J Clin Endocrinol Metab. 1985;61(6):1223-1225.

128. Levine BS, Rodman JS, Wienerman S, et al. Effect of calcium citrate supplementation on urinary calcium oxalate saturation in female stone formers: implications for prevention of osteoporosis. Am J Clin Nutr. 1994;60(4):592-596.

129. Sakhaee K, Baker S, Zerwekh J, et al. Limited risk of kidney stone formation during long-term calcium citrate supplementation in non stone forming subjects. J Urol. 1994;152(2Pt 1):324-327.

130. Sakhaee K, Poindexter JR, Griffith CS, et al. Stone forming risk of calcium citrate supplementation in healthy postmenopausal women. $J$ Urol. 2004;172(3):958-961.
131. Patel AM, Adeseun GA, Goldfarb S. Calcium-Alkali Syndrome in the Modern Era. Nutrients. 2013;5(12):4880-4893.

132. da Silva Ferreira T, Torres MR, Sanjuliani AF. Dietary calcium intake is associated with adiposity, metabolic profile, inflammatory state and blood pressure, but not with erythrocyte intracellular calcium and endothelial function in healthy pre-menopausal women. $\mathrm{Br} \mathrm{J}$ Nutr. 2013;110(6):1079-1088.

133. Livingstone KM, Lovegrove JA, Cockcroft JR, et al. Does dairy food intake predict arterial stiffness and blood pressure in men? Evidence from the Caerphilly Prospective Study. Hypertension. 2013;61(1):42-47.

134. Elwood PC, Pickering JE, Givens DI, et al. The consumption of milk and dairy foods and the incidence of vascular disease and diabetes: an overview of the evidence. Lipids. 2010;45(10):925-939.

135. Elwood PC, Pickering JE, Hughes J, et al. Milk drinking, ischaemic heart disease and ischaemic stroke II. Evidence from cohort studies. Eur J Clin Nutr. 2004;58(5):718-724.

136. Warensjö E, Jansson JH, Berglund L, et al. Estimated intake of milk fat is negatively associated with cardiovascular risk factors and does not increase the risk of a first acute myocardial infarction. A prospective case-control study. Br J Nutr. 2004;91(4):635-642.

137. de Vrese M, Pfeuffer M, Roos N, et al. The health aspects of milk. In: Griffiths, Mansel W, editors. Improving the safety and quality of milk: Improving quality in milk products. USA: Elsevier; 2010:28-61.

138. Bolland MJ, Barber PA, Doughty RN, et al. vascular events in healthy older women receiving calcium supplementation: randomised controlled trial. BMJ. 2008;336(7638):262-266.

139. Bolland MJ, Avenell A, Baron JA, et al. Effect of calcium supplements on risk of myocardial infarction and cardiovascular events: metaanalysis. BMJ. 2010;341:c3691.

140. Bolland MJ, Grey A, Avenell A, et al. Calcium supplements with or without vitamin D and risk of cardiovascular events: reanalysis of the Women's Health Initiative limited access dataset and meta-analysis. BMJ. 2011;342:d2040.

141. Li K, Kaaks R, Linseisen J, et al. Associations of dietary calcium intake and calcium supplementation with myocardial infarction and stroke risk and overall cardiovascular mortality in the Heidelberg cohort of the European Prospective Investigation into cancer and Nutrition study (EPIC-Heidelberg). Heart. 2012;98(12):920-925.

142. Xiao Q, Murphy RA, Houston DK, et al. Dietary and supplemental calcium intake and cardiovascular disease mortality: the National Institutes of Health-AARP diet and health study. JAMA Intern Med. 2013;173(8):639-646.

143. Jackson G. Calcium supplements and cardiovascular disease - A response. Int J Clin Pract. 2011;65(2):227-228.

144. Nordin BE, Daly RM, Horowitz J, et al. Calcium and heartattacks. Making too much of a weak case. BMJ. 2010;341:c4997.

145. Grove ML, Cook D. Calcium and heart attacks. Doesn't apply to most calcium prescriptions. BMJ. 2010;341:c5003.

146. Bostick RM, Kushi LH, Wu Y, et al. Relation of calcium, vitamin $\mathrm{D}$, and dairy food intake to ischemic heart disease mortality among postmenopausal women. Am J Epidemiol. 1999;149(2):151-161.

147. Lappe JM, Heaney RP. Calcium supplementation: Results may not be generalisable. BMJ. 2008;336(7641):403.

148. Weng LC, Wen-Ting Yeh, Chyi-Huey Bai, et al. Is ischemic stroke risk related to folate status or other nutrients correlated with folate intake? Stroke. 2008;39:3152-3158. 
149. Lewis JR, Radavelli-Bagatini S, Rejnmark L, et al. The effects of calcium supplementation on verified coronary heart disease hospitalization and death in postmenopausal women: a collaborative meta-analysis of randomized controlled trials. J Bone Miner Res. 2015;30(1):165-175.

150. Samelson EJ, Booth SL, Fox CS, et al. Calcium intake is not associated with increased coronaryartery calcification: the Framingham Study. Am J Clin Nutr. 2012;96(6):1274-1280.

151. Burt MG, Mangelsdorf BL, Srivastava D, et al. Acute effect of calcium citrate on serum calcium and cardiovascular function. JBMR. 2013;28(2):412-418.

152. Guessous I, Bochud M, Bonny O, et al. Calcium, vitamin D and cardiovascular disease. Kidney Blood Press Res. 2011;34(6):404-417.

153. Daly RM, Ebeling PR. Is excess calcium harmful to health? Nutrients. 2010;2(5):505-522.

154. Lewis JR, Calver J, Zhu K, et al. Calcium supplementation and risk of atherosclerotic vascular disease in older women. $J$ Bone Miner Res. 2011;26(1):35-41.

155. LaCroix AZ, Kotchen J, Anderson G, et al. Calcium plus vitamin D supplementation and mortality in postmenopausal women: The Women's Health Initiative calcium- Vitamin D Randomized Controlled Trial. J Gerontol A Biol Sci Med Sci. 2009;64(5):559-567.

156. Shah SM, Carey IM, Harris T, et al. Calcium supplementation, cardiovascular disease and mortality in older women. Pharmacoepidemiol Drug Saf. 2010;19(1):59-64.

157. Mursu J, Robien K, Harnack LJ, et al. Dietary supplements and mortality rate in older women. The Iowa Women's Health Study. Arch Intern Med. 2011;171(18):1625-1633

158. LaCroix AZ, Kotchen J, Anderson G, et al. Calcium plus vitamin D supplementation and mortality in postmenopausal women: The Women's Health Initiative calcium- vitamin D randomized controlled trial. J Gerontol A Biol Sci Med Sci. 2009;64(5):559-567.

159. Michaelsson K, Melhus H, Warensjö Lemming E, et al. Long term calcium intake and rates of all cause and cardiovascular mortality: community based prospective longitudinal cohort study. BMJ. 2013;346:f228.
160. Watts NB. Focus on primary care: postmenopausal osteoporosis an update. Obstet Gynecol Surv. 1999;55(12 Suppl 3):S49-S55.

161. Minihane AM, Fairweather-Tait SJ. Effect of calcium supplementation on daily nonheme-iron absorption and long-term iron status. Am J Clin Nutr. 1998;68(1):96-102.

162. Cook JD, Dassenko SA, Whittaker P. Calcium supplementation: effect on iron absorption. Am J Clin Nutr. 1991;53(1):106-111.

163. Straub DA. Calcium supplementation in clinical practice: a review of forms, doses, and indications. Nutr Clin Pract. 2007;22(3):286-296.

164. Gao X, LaValley MP, Tucker KL. Prospective studies of dairy product and calcium intakes and prostate cancer risk: a meta-analysis. $\mathrm{J} \mathrm{Natl}$ Cancer Inst. 2005;97(23):1768-1777.

165. Koh KA, Sesso HD, Paffenbarger RS, et al. Dairy products, calcium and prostate cancer risk. Br J Cancer. 2006;95(11):1582-1585.

166. Huncharek M, Muscat J, Kupelnick B. Dairy products, dietary calcium and vitamin D intake as risk factors for prostate cancer: a metaanalysis of 26,769 cases from 45 observational studies. Nutr Cancer. 2008;60(4):421-441.

167. Bristow SM, Bolland MJ, MacLennan GS, et al. Calcium supplements and cancer risk: a meta-analysis of randomized controlled trials. $\mathrm{Br} J$ Nutr. 2013;110(8):1384-1393.

168. Kavanaugh CJ, Trumbo PR, Ellwood KC. Qualified health claims for calcium and colorectal, breast, and prostate cancers: The U.S. Food and Drug Administration's evidence-based review. Nutr Cancer. 2009;61(2):157-164.

169. Weingarten MA, Zalmanovici A, Yaphe J. Dietary calcium supplementation for preventing colorectal cancer and adenomatous polyps. Cochrane Database Syst Rev. 2005;(3):CD003548.

170. Uusi-Rasi K, Kärkkäinen MU, Lamberg-Allardt CJ. Calcium intake in health maintenance - a systematic review. Food Nutr Res. 2013;57:21082-21097. 